Historic, archived document

Do not assume content reflects current scientific knowledge, policies, or practices. 



\section{Your Garden Next Spring}

September - October 1966

Published by:

The Netherlands Flower-bulb Institute The Associated Bulb Growers of Holland

Hillegom

The Netherlands

\section{On the covers}

Nestled in front of the shrub background is an example of the Darwin Hybrid class of tulips. These are the giants of the tulip world; brilliant flowers on tall, strong stems.

On the back cover is one of the many two-tone varieties found among tulips. This Triumph, which blooms in mid season, gives us carmine flowers edged with white. Tulips have the added advantage of remaining fresh a long time after cutting to give double duty beautifying the outdoors and indoors.

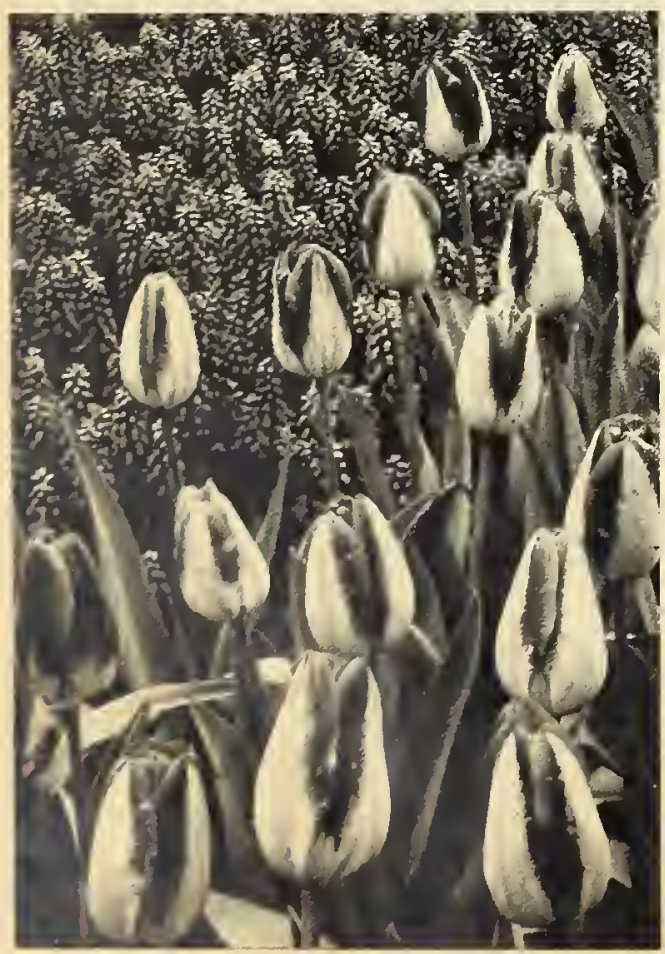

\section{Beautify America A tribute to Mrs. Johnson}

This issue of "Your Garden Next Spring" is dedicated to Mrs. Ladybird Johnson for her devoted work and inspiration in the Beautify America Program.

What started as a campaign to beautify highways, spearheaded by President Lyndon B. Johnson, has now broadened to include every nook and cranny in our country. The Beautify America Program is being brought to every dooryard and home garden through the efforts of Mrs. Johnson, the First Lady of the Land.

Federal, State and local governments are expending millions of dollars to make the landscapes bordering highways and cities things of beauty. Where this program ends, the homeowner can begin. Even the single touch of color, such as the Winter aconite (above picture 1) poking its head through the late Spring snow, can be significant in the "townscape".

With each buib that opens into its full glory in early Spring, another touch of color is added to the overall beauty of the garden. A beautiful home garden, added to innumerable others, blends into the total community of beauty and color. This is how homeowners and gardeners from coast to coast can add their contribution to the Beautify America Program.

Like an artist touching his brush from pallet to canvas, we can put our touch on the gigantic painting which, when completed, will be the masterpiece of a more beautiful land. A dot of pigment is not a picture unto itself, but is often the necessary mark of completion.

No matter how small your garden, it is a part of the great American landscape and picture.

No other gardening season is enjoyed more than early Spring. It is indeed the awakening of new plant life - often before the last snows have left the ground. But, as Nature herself prepares for her blaze of color long in advance, your garden next Spring must receive its start this Fall.

Planting this Autumn will assure you a more colorful garden next Spring and enable you to make your contribution to a more beautiful land.

"A thing of beauty is a joy forever: Its loveliness increases; it will never Pass into nothingness."

John Keats 
Every item marked " has been selected in Holland this spring as one of the ten most admired varieties of the year. The number in front of each type of bulb refers to the bloomingtime of that type of bulb or variety:
$1=$ March Blooming
$2=$ March-April Blooming
$3=$ April-May Blooming
4 = May Blooming.

For the prices of the items featured in this magizine, kindly check the back page of this list. Prices quoted includes postage.

\section{(4) Giant Long Stemmed Darwin - Cottage - Breeder Tulips}

For distinctive beauty and attractiveness Cottage-Breeder and Darwin Tulips are unsurpassed. Adapted to many useful purposes with their brilliant colors, their large flowers borne on tall graceful stems, their excellent substance and longlasting qualities, they create a beautiful picture in any garden.

Letter after variety denotes class of tulip: (C) Cottage. (Br) Breeder, (D) Darwin.

\section{GROUP I ECONOMICAL OLD FAVOURITES 12 for $\$ 1.10 \quad 25$ for $\$ 2.00 \quad 100$ for $\$ 7.30$}

CLARA BUTT, (D) Splendid bedder. Beautiful soft salmon-rose flowers borne on tall stems.

CUM LAUDE, (D) deep campanula-violet large and broad flower somewhat waved at the edge of the petals.

DILLENBURG $(\mathrm{Br})$ clear glowing orange-terracotta. ECLIPSE. (D) Large, strikingly attractive deep crimson with blue base. Tall stiff stems.

GOLDEN HARVEST, (C) Large flowers of soft yellow with ivory stamens and of great substance.

MAGIER, (C) milky white with a margin of violet-blue, which spreads over the whole flower as it ages.

PRINCESS MARGARET ROSE, (C) clear canary-yellow, edged orange-red.
QUEEN OF NIGHT, (D) deep blackish maroon. Large flower on strong stem.

SPRING SONG, (D) bright red with small white base. Excellent bedding tulip.

SCARLETT O'HARA, (D) Brilliant scarlet flower with a lighter shade to the edge.

WHITE LEADER, (D) A remarkable white tulip with white base and anthers and perfectly shaped.

\section{MIXTURE OF ALL COLORS OF THE RAINBOW}

Especially attractive where bright showy colors are desired. 12 for $\$ 1.0525$ for $\$ 1.85$ 50 for $\$ 3.65100$ for $\$ 6.95$

\section{GROUP \|I OUR CHOICE OF THE FINE NEWER VARIETIES}

\section{2 for $\$ 1.40 \quad 25$ for $\$ 2.70 \quad 100$ for $\$ 9.75$}

AMERICAN FLAG, (D) Deep red with broad white lines, blue base, very attractive variety.

FLORENCE NIGHTINGALE, (D) Very bright vermilionred, with glistening sheen. The flower is broad and substantial.

GOLDEN NIPHETOS, (D) Gleaming gold with soft yellow center. Large oblong flower with lasting qualities.

HALCRO, (C) Large long shaped flower of carminered. Excellent.

INSURPASSABLE, (D) lilac flower on a tall strong stem.

HELEN MADISON, (D) Beautiful rose pink inside claret, white base. The flower is carried on a strong stem.

MAUREEN, (C) Marble white oval shaped flower. Large and substantial.
MRS. JOHN T. SCHEEPERS, (C) Clear yellow. The enormous oval shaped flower is carried on a strong stem. A perfect garden tulip.

OXFORD, Darwin Hybrid, striking tomatored with purple glow, highly recommended.

PINK SUPREME, (D) Bright pink, somewhat lighter to the edges.

PRINCESS ELIZABETH, (D) Vivid rosy-pink. An excellent variety for the garden.

QUEEN OF BARTIGONS, (D) The only true salmon tulip. Outstanding in color.

SWEET HARMONY, (D) Lemon-yellow edged ivorywhite. Unique color combination.

SNOWPEAK, (D) Very large pure white flower of excellent shape on a tall stiff stem.

THE BISHOP, (D) Clear deep violet-blue. Excellent tulip with great substance. 
(3) DARWIN "HYBRID" TULIPS

12 for $\$ 1.4025$ for $\$ 2.70100$ for $\$ 9,75$

These outstanding new tulips are the result of a great many years of crossing and selection between the best Darwins and Fosteriana Red Emperor tulips. They are tall and the most perfect, the largest and strongest of all, truly wonderful. A small grouping in the garden will be the talk of the neighbourhood.

DIPLOMATE. The most brilliant vermilion-scarlet red ever seen. The large, egg-shaped flowers are carried on sturdy stems.

GENERAL EISENHOWER. An exceptional large flower, orange-red in color.

GUDOSHNIK. Sulphur-yellow, spotted salmon-red. An exquisite flower.

PRESIDENT KENNEDY. Opens as a light yellow tulip with a orange undertone and as the flower matures the color changes into a beautiful light orange.

12 for $\$ 1.60 \quad 25$ for $\$ 3.35 \quad 100$ for $\$ 12.50$

EXTRA EARLY SPECIES OR BOTANICAL TULIPS

12 for $\$ 1.60 \quad 25$ for $\$ 2.95 \quad 100$ for $\$ 10.50$

Ouite different in habit and uses from all other tulips, they are becoming increasingly popular. They are wonderful for grouping in rockgardens and hardy borders, where they come up year after year.

(2) FOSTERIANA RED EMPEROR. 18" The great and famous tulip. Bright vermilion-scarlet flower of remarkable size. This is a must.

(2) FOSTERIANA WHITE EMPEROR. 18". Its white colour shows a touch of very light primrose on the outside petals. It blooms early like the Red Emperor.

Greigii. T. PANDOUR, YELLOW flamed crimsonred. $12^{\prime \prime}$ high.

(3) GREIGII RED RIDING HOOD. 6". Oriental-red, brownish-purple spreading leaves. The whole plant is as charming as the little girl in the fairy tale.

(1) KAUFMANNIANA CEASAR FRANCK. 8". Bright crimson-scarlet, edged rich yellow. The earliest tulip. Kaufm. Tulip CONCERTO, lovely sulphur-yellow with gold overlay. Brownish-red heart. 14" high. Most beautiful.

Kaufm. Tulip PRIMROSE. 8" high. Delicate soft yellow.

- KAUFMANNIANA SHAKESPEARE. 8". Beautiful

(1) blending of salmon, apricot and orange, shaded with red inside. Outstanding.

\section{(4) GRACIOUS LILY FLOWERING TULIPS}

12 for $\$ 1.5025$ for $\$ 2.75100$ for $\$ 9.75$

Elegantly shaped flowers with long pointed and reflexed petals on tall stems. Splendid for groups in borders and very artistic when cut.

CHINA PINK. A very fine china-doll-pink flower with white base.

DYANITO. 18" high Fine red. Stately.

GOLDEN DUCHESS. Golden yellow, large flower of great beauty.

QUEEN OF SHEEBA, red with narrow yellow border. RED SHINE. A very large graceful shaped deep red flower on a strong stem.
WHITE TRIUMPHATOR. Beautiful tulip of artistic form, the color is snow-white throughout.

(4) PARROT TULIPS

12 for $\$ 1.5025$ for $\$ 2.75100$ for $\$ 9.75$

Extravagant-looking Tulips with toothed feathered and fringed blooms. In bright sunshine they open flat to a fantastic size. They are wonderful cutflowers.

BLEU PARROT. Delightful lilac-blue, very substantial flower on an erect stem.

ORANGE FAVORITE. Striking orange.

RED PARROT. Raspberry-red with a faint blue tone.

TEXAS GOLD. Clear yellow, slightly rimmed bright red.

VAN DYK. Bright rose-pink, large flower, outstanding in colour and form.

WHITE PARROT. Pure white, distinctly marked green.

(3) PEONY TULIPS

12 for $\$ 1.5025$ for $\$ 2.75100$ for $\$ 9.75$

Fully double flowers of huge size, on strong erect stems, resembling Peonies in form.

BRILLIANT FIRE. Bright vermilion-red. Excellent.

EROS. Very large flower of clear old rose. This sweet scented tulip is a fine garden variety.

MOUNT TACOMA. The large flower is very much resembling a double white peony.

NIZZA. Soft yellow, strongly flaked with bright red.

ORANGE TRIUMPH. Orangered, yellow border.

(3) INTERMEDIATE TRIUMPH -

SINGLE EARLY TULIPS - MENDEL

12 for $\$ 1.5025$ for $\$ 2.75100$ for $\$ 9.75$

They are useful for the garden, due to their strong stems and because they fill the gap between the very early and the late tulips. They are also excellent for indoor growing.

GARDEN PARTY. Glittering white and crimson.

GENERAL DE WET. Fiery orange, stippled scarlet. yellow center.

ORANGE WONDER. Striking orange-red.

PARIS. Beautiful red and deep yellow.

PRINCE OF AUSTRIA. Red.

PRINCE CARNIVAL. Orange-red with yellow stripes and blotches, sweet scented.

SULPHUR GLORY. One toned chrome-yellow, strong stem.

TEHERAN. Light suffused yellow with distinct red border. Striking color combination.

(4) AMAZING BUNCH FLOWERING TULIPS 12 for $\$ 1.5025$ for $\$ 2.75100$ for $\$ 9.75$

This type of tulips produces three and more flowers on each stem. Very unusual and handsome.

GEORGETTE. Fine novelty of clear yellow, edged red very outstanding.

WALLFLOWER. Dark brownish-red with yellow base. 


\section{Narcissi}

The flowering season of Narcissi begins extremely early and lasts until quite late. As cutflowers they have few equals. Culture is the easiest possible. Narcissi multiply quite freely and bloom profusely year after year.

(2) DAFFODILS - TRUMPET NARCISSI 12 for $\$ 2.6025$ for $\$ 4.75100$ for $\$ 16.95$

BEERSHEBA. The pure white perianth and trumpet are well-proportioned, an elegant flower.

DUTCH MASTER. This flower is golden yellow throughout and has an overlapping perianth and the trumpet is nicely fringed at the mouth.

GOLDEN HARVEST. Large yellow. Blooms early. Very showy.

KING ALFRED. The most popular daffodil on earth. Its golden yellow colour and bold trumpet have made it a universal favourite.

MOUNT HOOD. Ivory-white perianth with large creamy-white trumpet, heavily flanged and imbricated at the mouth.

PINK HORIZON. Pure white well-formed perianth, the trumpet shaped cup is of a delicate lilac-rose.

PRESIDENT LEBRUN. Deep yellow trumpet with pure white perianth. Excellent.

QUEEN OF THE BICOLORS. Large yellow trumpet against pure-white perianth.

UNSURPASSABLE. Definitely a show flower, extremely large, golden-yellow throughout.

\section{(2) LARGE CUPPED NARCISSI}

12 for $\$ 2.00 \quad 25$ for $\$ 3.65 \quad 100$ for $\$ 12.95$

CARLTON. Broad overlapping flat perianth with a large expanded cup. The whole flower is of a uniform yellow. Very free flowering and a rapid grower. DUKE OF WINDSOR. Thick pure white segments, with a broad beautifully ruffled orange-red cup.

RED MARLEY. Golden yellow perianth with a large heavily fringed trumpet shaped crown, which is orange-red and does not fade.

SCARLET ELEGANCE, Dark yellow and orange cup.

SPRING BRIDE. Star shaped ivory-white perianth with a clear frilled crown.

\section{(3) SMALL CUPPED NARCISSI}

12 for $\$ 1.8525$ for $\$ 3.35100$ for $\$ 11.95$

ACTAEA. Broad snow-white perianth of solid texture, petals well-overlapped, canary-yellow cup, red edged. Excellent for naturalizing.

POMONA. Pure white perianth, sulphur-yellow cup with red margin and green center.

\section{SPECIE - ROCKGARDEN NARCISSI}

(2) BULBOCODIUM. The Hoop Petticoat Daffodil. Unusual flowers having rich golden yellow trumpets of hoop petticoat form and rush like foliage.

12 for $\$ 1.10 \quad 25$ for $\$ 1.80 \quad 100$ for $\$ 6.75$

(1) FEBRUARY GOLD. A golden yellow miniature trumpet with reflexing petals.

12 for $\$ 2.25 \quad 25$ for $\$ 3.95 \quad 100$ for $\$ 14.95$

(4) JONQUIL SIMPLEX. The true single sweet Jonquil. Dainty heads of small rich yellow fragrant flowers. Rush-like foliage.

12 for $\$ 0.95 \quad 25$ for $\$ 1.85$

100 for $\$ 6.95$

(3) TRIANDRUS LIBERTY BELLS. Cluster flowering, pendant, deep lemon-yellow flowers with all the excellent qualities of the Triandrus Hybrids.

12 for $\$ 1.85 \quad 25$ for $\$ 3.40$

100 for $\$ 12.15$

(4) TRIANDRUS SILVER CHIMES. The four to six nodding flowers have pure white perianths and pale primrose cups. Very attractive.

12 for $\$ 1.95 \quad 25$ for $\$ 3.50 \quad 100$ for $\$ 12.45$

(3) TRIANDRUS THALIA. Three to four pure white flowers on one stem, highly recommended.

12 for $\$ 1.85 \quad 25$ for $\$ 3.35 \quad 100$ for $\$ 11.95$

(2) DOUBLE NARCISSI

12 for $\$ 2.0525$ for $\$ 3.70 \quad 100$ for $\$ 13.20$

MARY COPLAND. Outer petals are creamy-white and the center interspersed with orange-red. Strong stem. TEXAS. Very large full double flower of golden yellow interspersed with brilliant orange. Tall strong stem.

(3) POETAZ NARCISSI

12 for $\$ 1.85 \quad 25$ for $\$ 3.35 \quad 100$ for $\$ 11.95$

CHEERFULNESS. A very showy and decorative variety with two or three blooms on a strong stem, white perianth and a full double creamy-white center.

GERANIUM. Excellent, perianth pure white and a flat cup of an intense orange-scarlet. There are four or more flowers on a strong stem.

YELLOW CHEERFULNESS. Yellow sport of the regular Cheerfulness with all its good qualities.

\section{NARCISSI FOR INDOOR CULTURE Imported from France.}

12 for $\$ 1.95 \quad 25$ for $\$ 3.50 \quad 100$ for $\$ 12.45$

PAPERWHITE NARCISSI. The best known and loved and easiest to grow of all bulbous flowers for indoor culture. A cluster of white flowers on each stem.
GRAND SOLEIL D'OR. The same as the Paperwhites, except the perianth is golden yellow and the tiny cup of an orange-yellow. 


\section{Naturalizing Narcissi and Daffodil Mixture}

This mixture is made by our Dutch grower. It includes a wide range of varieties in varied sizes, shapes, types and colours, all especially adapted for planting in woodlands and places where mass flowering is desired.
12 for $\$ 1.60$
25 for $\$ 2.95$
50 for $\$ 5.70$
100 for $\$ 10.75$

(2) HYACINTHS
For fragrance and beauty.
(The queen of the spring flowers)
Exhibition size $(18 / 19 \mathrm{~cm})$
12 for $\$ \begin{array}{lll}3.20 \quad 25 \text { for } \$ 5.80 \quad 100 \text { for } \$ 20.70 \\
\text { Extra bedding size }(15 / 16 \mathrm{~cm})\end{array}$
12 for $\$$\begin{tabular}{lll}
$1.95 \quad 25$ for $\$ 3.65 \quad 100$ for $\$ 12.95$ \\
\hline
\end{tabular}

Hyacinths never fail to catch the admiration and affection of flower lovers. With their wide range of colors, their earliness, uniformity in height and fragrance, hyacinths will fill your expectations of spring for many years to come.

CITY OF HAARLEM. Pale yellow, large spike.

IAN BOS. Carmine-red, tinted scarlet, lighter center. Early.

L'INNOCENCE. Pure white, large bells, also excellent for forcing.

OSTARA. Deep blue, large truss, excellent forcer.

PERLE BRILLIANT. Fine light blue, large broad spike. PINK PEARL. Pink, very early, excellent forcer.

PRINCESS IRENE, rose-pink.

(4) FANCY DUTCH IRIS
12 for $\$ 0.90 \quad 25$ for $\$ 1.65 \quad 100$ for $\$ 5.95$

Once established, these Irises increase rapidly. Practically unsurpassed as cutflowers, lasting for a long time. Also called "A poor man's orchid".

ANGEL's WINGS. White, deep yellow falls, orange blotch.

BLUE CHAMPION. Porcelain blue, yellow blotch.

GOLDEN HARVEST. Yellow.

KING MAUVE. Violet-mauve, with clear mauve blotch. LE MOGOL. Mahogany-bronze, yellow blotch.

PROFESSOR BLAAUW. Deep velvety blue, large flowers.

SUNSHINE, Bringt-yellow, with orange falls.

WEDGEWOOD. Light blue, earliest for forcing.

WHITE EXCELSIOR. Pure white.

\begin{tabular}{|c|c|}
\hline \multicolumn{3}{|c|}{ MIXTURE OF DUTCH IRIS } \\
12 for $\$ 0.70 \quad 25$ for $\$ 1.25 \quad 100$ for $\$ 4.50$ \\
\hline 12 for $\$ 0.70 \quad \begin{array}{l}\text { (1) CROCUS } \\
25 \text { for } \$ 1.35 \quad 100 \text { for } \$ 4.75\end{array}$ \\
\hline
\end{tabular}

The most cheerful spring flower for beds, borders and in lawns or woodlands.

LITTLE DORRIT. Amethyst-blue with silvery sheen, one of our finest crocus.

PETER PAN. Pure white, orange stigmata.

PICKWICK. Silvery-lilac with dark lilac stripes. A distinct combination of colors.

PURPUREA GRANDIFLORA. Purple, excellent for forcing.

YELLOW MAMMOUTH. Golden yellow.

CROCUS MIXTURE, of all above mentioned colors.

12 for $\$ 0.6025$ for $\$ 1.25100$ for $\$ 4.25$

\section{PEONIES}

Healthy, vigorous, northern-grown, 3 to 5 -eye divisions, individually wrapped and labeled, with cultural directions.

SARAH BERNHARDT. Dark pure pink, edged a trifle lighter; very large. Midseason to late.

FESTIVA MAXIMA. Pure white flecked with carmine; enormous, full double flower. Early.

FELIX CROUSSE. A fine all-round red for cut flowers. Available in quantity. Rich ruby-red.

PRIMEVERE. The nearest to yellow. Anemone type; large canary-yellow center, blush-white outer petals. Early midseason.

Each $\$ 1.00$ 3for $\$ 2.856$ for $\$ 5.4012$ for $\$ 10.20$, postpaid.

\section{The pretty little things}

Plant little groups of these all over the garden. They are quite hardy and will come back year after year.

(3) ANEMONES. Bright, long lasting flowers, especially desirable for cutting. ... $\quad \ldots \quad \ldots \quad 0.70$

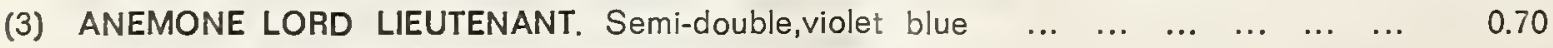

(3) ANEMONE MOUNT EVEREST. Semi-double, white $\ldots \begin{array}{lllllllllll} & \ldots & \ldots & \ldots & \ldots & \ldots & \ldots & \ldots & \ldots & 0.70\end{array}$

(3) ANEMONE THE ADMIRAL. Semi-double, rose-violet $\ldots \begin{array}{lllllllllll} & \ldots & \ldots & \ldots & \ldots & \ldots & \ldots & \ldots & 0.70\end{array}$

(3) ANEMONE THE GOVERNOR. Semi-double, brilliant-red $\ldots \begin{array}{llllllllll} & \ldots & \ldots & \ldots & \ldots & \ldots & \ldots & \ldots & 0.70\end{array}$

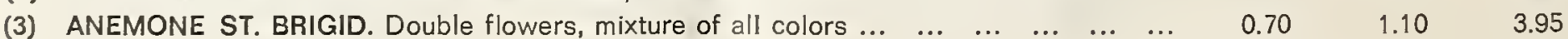


(3) ANEMONE DE CAEN SINGLE. A mixture of all colors $\ldots \begin{array}{lllllllllll} & \ldots & \ldots & \ldots & \ldots & \ldots & \ldots & \ldots & 0.60 & 1.10 & 3.95\end{array}$

(3) ANEMONE BLANDA. Blue, very early $\ldots \begin{array}{llllllllllll}\ldots & \ldots & \ldots & \ldots & \ldots & \ldots & \ldots & \ldots & \ldots & \ldots & \ldots\end{array}$

(1) CHIONODOXA LUCILIAE. (Glorie of the Snow) $5^{\prime \prime}$. Sky-blue with a white center. Very early. Once established, they become increasingly beautiful for years $\quad \ldots \quad \ldots \quad \ldots$

(1) ERANTHIS (Winter Aconite) $3^{\prime \prime}$. Golden yellow, very early, very free flowering ... ...

(3) FRITILLARIA MELEAGRIS (Guinea Hen Flower) 12". Reddish brown, and purple bell-

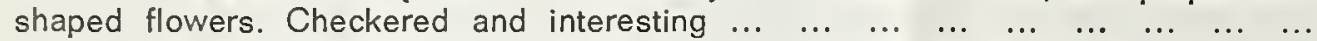

(1) GALANTHUS (Snowdrops) 4". Lovely white, nodding blooms. The earliest of the spring heralds; their persistency is noteworthy and they will thrive anywhere $\ldots \ldots \ldots$

$0.60 \quad 1.10 \quad 3.95$

(1) IRIS SPECIE DANFORDIAE. Bright yellow, $6 "$ "

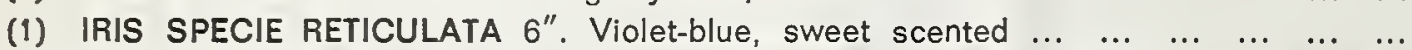

(4) IXIA MIXTURE. These little bulbs are mostly used for cutflowers, 18". A wide array of colour. They prefer sunny area's $\ldots \begin{array}{lllllllllllll} & \ldots & \ldots & \ldots & \ldots & \ldots & \ldots & \ldots & \ldots & \ldots & \ldots & \ldots\end{array}$

(3) LEUCOJUM AESTIVUM (Snowflake). Produces clusters of white bell-shaped flowers

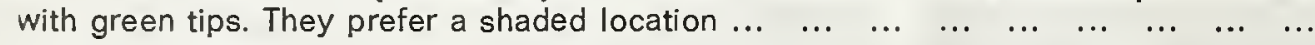

(2) MUSCARI HEAVENLY BLUE (Grape Hyacinths) 5". Charming spikes of clear blue

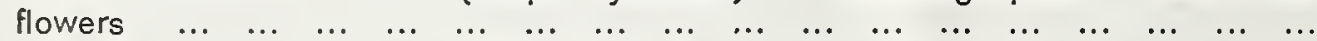

(2) MUSCARI ALBA (White Grape Hyacinths) 5 ". Somewhat smaller than the blue one

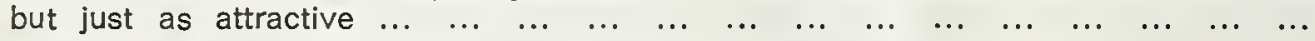

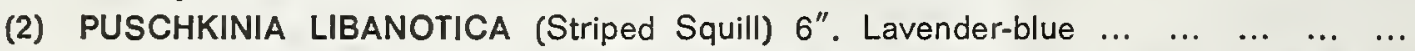

(4) RANUNCULUS. Peony Flowering Mixture. The only type that is realy suitable for the garden. Excellent brilliant colour mixture of large well-filled double flowers ...

(4) SCILLA CAMPANULATA 15" (Wood Hyacinths or Blue Bells). In white, pink or blue and mixed. Very long lasting and exceptional suitable for naturalizing and will $\begin{array}{llllllllllllllll}\text { thrive anywhere } & \ldots & \ldots & \ldots & \ldots & \ldots & \ldots & \ldots & \ldots & \ldots & \ldots & \ldots & \ldots & \ldots & \ldots & \ldots\end{array}$

(3) SCILLA SIBERICA SPRING BEAUTY 5" (Siberian Squill). Producing fragrant drooping bell like flowers. Delphinium blue, very attractive. They prefer a sunny location ...

$\begin{array}{lll}0.60 & 1.10 & 3.95 \\ 0.80 & 1.50 & 5.40 \\ 0.80 & 1.50 & 5.40 \\ 0.30 & 0.55 & 1.95 \\ 0.80 & 1.45 & 5.25 \\ 0.60 & 1.10 & 3.95 \\ 0.60 & 1.10 & 3.95 \\ 0.60 & 1.10 & 3.95 \\ 0.80 & 1.45 & 5.25 \\ & & \\ 0.65 & 1.20 & 4.35 \\ 0.75 & 1.40 & 5.10\end{array}$

\section{Lilies - stately - exotic - beautiful - fragrant}

REGALE. The well-known Regale Lily. This in one of the most beautiful and one of the hardiest lilies in cultivation. Flowers are flushed with yellow at center shading to white at the outer edges, on the outside they are marked with reddish shadings on the ribs. Grows from 4 to 6 feet tall.

3 for $\$ 1.80$

12 for $\$ 6.50$

25 for $\$ 12.50$

\section{Amaryllis}

Dutch Hybrids for indoor growing; available in red, pure white and pink. If ordered immediately you could have them in bloom by Christmas. Special plantinginstructions come with each bulb. The 3 to 5 lily-like flowers are huge and of a striking colour produced on a heavy stem.

$$
\text { Per bulb \$2.- } \quad 3 \text { for } \$ 5.40
$$

LILIUM CANDIDUM (Madonna Lily). These emblems of heavenly purity are among the best known and most popular of all garden Lilies. Hardy and one of the easiest in culture, enduring sun and shade. Pure white flowers borne 8 to 12 on a 3 to 4 feet stem, are delightfully fragrant. Bloom in June.

3 for $\$ 1.35$

12 for $\$ 4.50$

25 for $\$ 8.30$

\section{French Roman Hyacinths}

These small Hyacinths differ from the large spike varieties in that they produce numerous spikes of scattered flowers. Their delightful fragrance and graceful habit makes them ideal for gardens, for indoor culture in pots or bulb fiber and for cutting. The white is especially fine for indoor use.

Pink per $12 \$ 2.45$

White per $12 \$ 3 .-$

Blue per $12 \$ 1.85$

per $25 \$ 4.45$

per $25 \$ 5.30$

per $25 \$ 3.50$

per $100 \$ 15.95$

per $100 \$ 19.65$

per $100 \$ 14.05$

\section{(2) Fritillaria Imperialis "Crown Imperial"}

This large bulb produces thick clusters of orange flowers, suspended under a tuft of green leaves on stout stems standing three feet high. Planted in a group of 3 or 5 will give you a very impressive and attractive spot in your garden.

1 for $\$ 0.98 \quad 3$ for $\$ 2.80$

12 for $\$ 10.80$ 


\section{Varieties featured in this magazine}

Frontcover

Darwin Hybrid OXFORD, striking tomatored with slight purple glow,

Per 12

25

100

$\$ 1.40$

2.70

Picture No. 1. ERANTHIS HYEMALIS (Winter Aconites) golden yellow ... $\ldots . .$.

2. Triumph T. GARDEN PARTY, snowwhite and crimsonred ... $\quad . . \quad \ldots$

2. Darwin Hybrid GUDOSHNIK, sulphuryellow spotted red ... ... ...

3. Triumph T. GARDEN PARTY, glittering white and crimson ... $\quad . . \quad \ldots$

3. Narc. Poetaz CHEERFULNESS, double white and cream ... $\ldots . .$.

3. Triumph T. PARIS, beautiful red and deep yellow ... $\quad \ldots$...

3. Hyacinth JAN BOS, splendid carmine-red, tinted scarlet $\ldots \quad \ldots \quad \ldots$

3. Narcissus Inc. DUKE OF WINDSOR, white and yellow, showy $\ldots$ 3. In far corner to the right, HYBRID T. Greigii RED RIDING HOOD,
scarlet with brownish purple leaves

3. Triumph T. GUDOSHNIK, sulphur-yellow spotted red ... $\ldots . . . . \quad \ldots$

3. In foreground, MUSCARI, (Grape Hyacinths) heavenly blue ... ...

4. Crocus PICKWICK, silvery lilac with dark lilac stripes ... $\quad \ldots \quad \ldots \quad \ldots$

5. CROCUS MIXED in BLUE, WHITE AND YELLOW $\ldots \ldots \ldots$

6. LEUCOJUM AESTIVUM, Snowflake, clusters of bellshaped flowers
with small green tips. They like a shady spot ... $\ldots \ldots \ldots$
. . . .

7. Crocus PETER PAN and LITTLE DORRIT, gems of beauty ... ... $\ldots$

8. GALANTHUS (Snowdrops) lovely white, nodding blooms ... ... ...

9. Kaufm. Tulip CONCERTO, lovely sulphur-yellow with gold overlay. Brownish-red heart. 14" high. Most beautiful

10. Kaufm. Tulip SHAKESPEARE, pink with red inside. $8^{\prime \prime}$ high ... ... ...

11. Kaufm. Tulip PRIMROSE. 8 " high. Delicate soft yellow ... $\ldots . . . .$.

12. Greigii. T. PANDOUR, YELLOW flamed crimsonred. 12" high ... ...

13. Fosteriana RED EMPEROR. 18". The best in vermilion scarlet. Unsurpassed in size and beauty

14. FRITILLARIA IMPERIALIS, Red. Very showy. Each $0,98 \quad 3$ for 2,80

15. FRITILLARIA MELEAGRIS. Guinea Hen Flower, Redisch brown and purple bell-shaped flowers

16. Narcissus. Poeticus ACTEA, snow-white perianth with canary-yellow cup, red edged. Excellent for naturalizing

17. Narcissus. SCARLET ELEGANCE, dark yellow and orange cup ... $\ldots$

18. Narcissus. YELLOW CHEERFULNESS, beautiful double yellow, late blooming. Good for naturalizing

19. Double Peonyflowered T. BRILLANT FIRE AND NIZZA

20. Parrot T. ORANGE FAVORITE, striking orange $\ldots \ldots \ldots$

21. Double Peonyfl. ORANGE TRIUMPH, orangered, yellow border ... ...

22. Lilyflowered T. DYANITO, $18^{\prime \prime}$ high. Fine red. Stately ...

23. Lilyflowered T. GOLDEN DUCHESS, charming yellow, refined ... ...

24. Lilyfi QUEEN OF SHEEBA, red with narrow yellow border ...

25. CHIONODOXA LUCILAE, (Glory of the Snow) $5^{\prime \prime}$. Lovely skyblue with white center, Very early..

26. Hybrid Darwin. GENERAL EISENHOWER, Very large orangered

27. PUSCHKINIA LIBANOTICA, (Striped Squill) 6" light lavender blue

28. ANEMONES BLANDA, Blue. very early. Lowgrowing

29. Along water's edge. Narcissus. Triandus THALIA 3 to 4 pure-white flowers on one stem. Very lovely In foreground, Hyacinth PINK PEARL, deep pink $\begin{array}{llllll} & \cdots & & & & \end{array}$

30. Mendel T. ORANGE WONDER, striking orange-red $\ldots \quad \ldots \quad \ldots \quad \ldots$

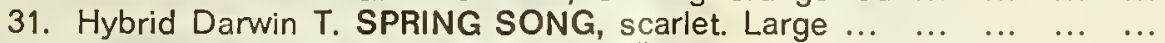

32 Fosteriana T. WHITE EMPEROR, 18". white $\ldots \begin{array}{llllll} & \ldots & \ldots & \ldots & \ldots & \ldots\end{array}$

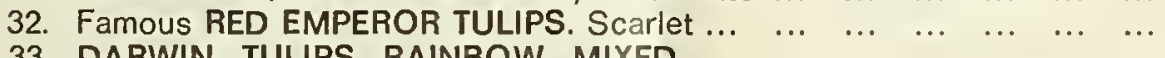

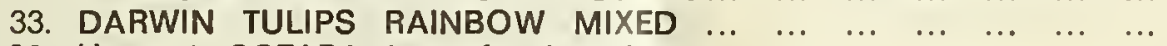

36. Hyacinth OSTARA, beautiful deep blue $\ldots \begin{array}{lllllll}\ldots & \ldots & \ldots & \ldots & \ldots & \ldots & \ldots\end{array}$

37. Top Left, Narc. GOLDEN HARVEST, Large yellow $\ldots \ldots$... $\ldots$... Next, Single Early T. PRINCE OF AUSTRIA, red
Daffodil Queen of the BICOLORS. large yellow trumpet

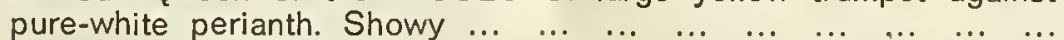
$\begin{array}{lllllllll}\text { Hyacinth JAN BOS, fiery red } \ldots & \ldots & \ldots & \ldots & \ldots & \ldots & \ldots & \ldots & \ldots\end{array}$

Triumph Tulip TEHERAN, light suffused yellow with distinct red border. Striking color combination. Strong sturdy variety ... $\ldots$. $\ldots \ldots \ldots$ In background. Solid mass of Muscari (Grape Hyacinths) Heavenly Blue

\subsection{0}

1.40

1.10

1.40

1.85

1.50

1.95

2.-

1.60

1.10

0.60

0.70

0.60

0.80

0.70

0.60

1.60

1.60

1.60

1.60

1.60

10.80

0.60

1.85

2.-

1.85

1.50

1.50

1.50

1.50

1.50

1.50

0.45

1.55

0.60

0.75

1.85

1.95

1.50

1.10

1.60

1.60

1.05

1.95

2.60

1.50

2.60

1.95
1.10

2.70

2.-

2.70

3.35

2.75

3.65

3.65

2.95

2.-

1.10

1.35

1.25

1.45

1.35

1.10

2.95

2.95

2.95

2.95

2.95

1.10

3.35

3.65

3.35

2.75

2.75

2.75

2.75

2.75

2.75

0.80

2.85

1.10

1.40

3.35

3.65

2.75

2.-

2.95

2.95

1.85

3.65

4.75

2.75

4.75

3.65
3.95

7.30

9.75

11.95

9.75

12.95

12.95

10.50

7.30

3.95

4.75

4.25

5.25

4.50

3.95

10.50

10.50

10.50

10.50

10.50

3.95

11.95

12.95

11.95

9.75

9.75

9.75

9.75

9.75

9.75

2.85

10.20

3.95

5.10

11.95

12.95

9.75

7.30

10.50

10.50

6.95

12.95

16.95

9.75

16.95 11.95 



\section{The choice is wide}

Every climate with its own distinctive beauty can be found within the boundaries of the United States and Canada. Almost every ornamental plant and bulb flower known to man will find a welcome home in a garden somewhere within these territorial limits.

The choice of plants for garden use is extremely wide. Even those plants often thought as being for one particular area can be grown and flowered successfully in others. This expansion of the world of garden beauty will add much to the overall picture of a beautiful America.

No longer are the stately tulips and fragrant hyacinths from Holland, for example, only for northern gardeners. Southern and West Coast flower lovers are growing and enjoying selected varieties of these Spring glories.
By planting a month or two later than the recommended time for northern gardeners, people in warmer areas can also have beautiful Spring gardens although they will bloom earlier than those in the North.

The Spring garden can have bloom for some two months, from the time of the early minor bulbs to the last tulips. But the pinnacle of Spring, no doubt, is when varieties of tulips, daffodils and hyacinths give forth a riot of rainbow color at the same time. Pictured here (pictures 2 and 3) are scenes of a garden at the height of bulb bloom. Tulips, daffodils, hyacinths, grape hyacinths, combined with pansies and other garden plants, shout that this is truly Spring.

The steps in this - and your garden can lead to the supreme in Spring enjoyment with bulb flowers.
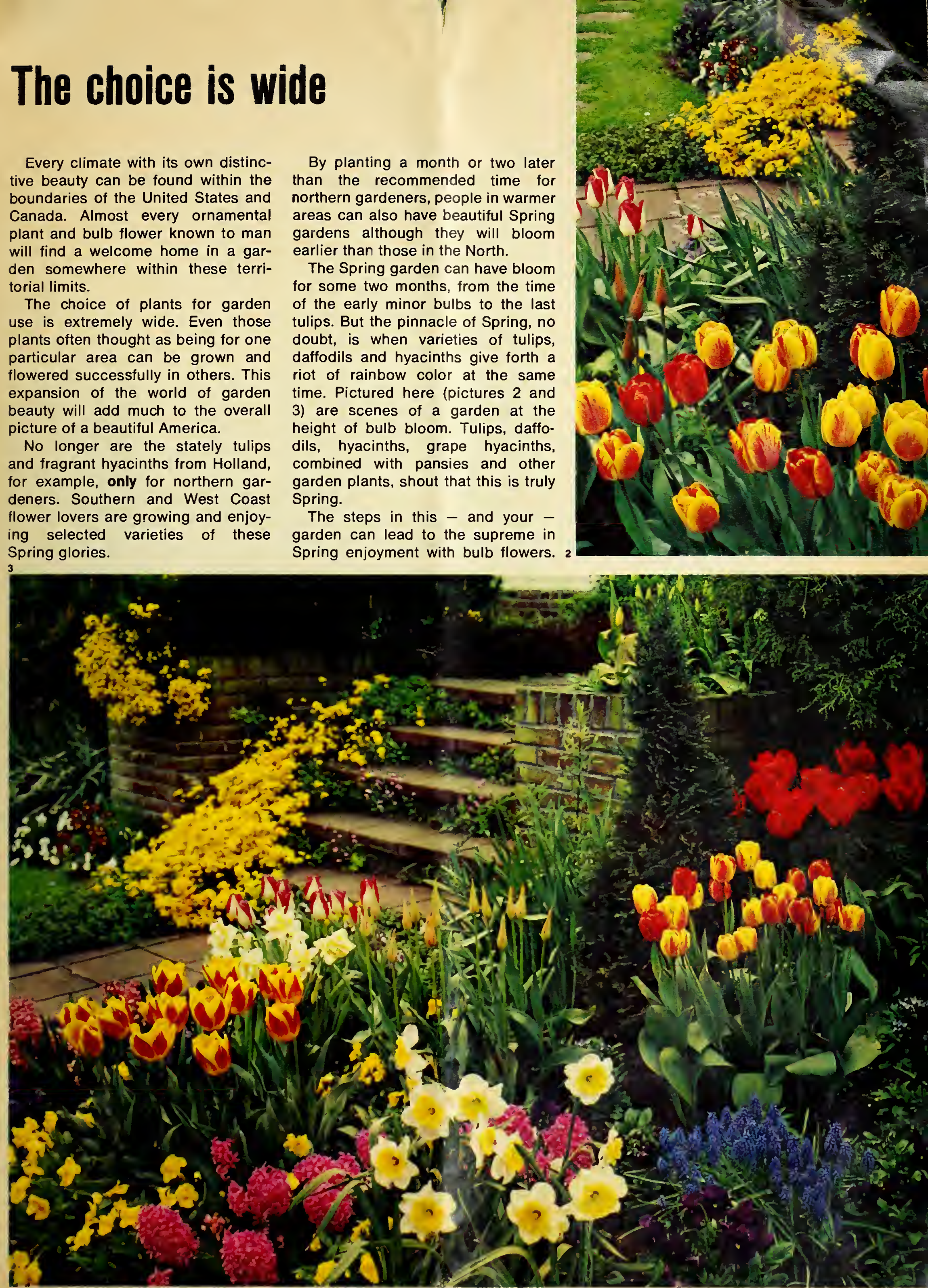


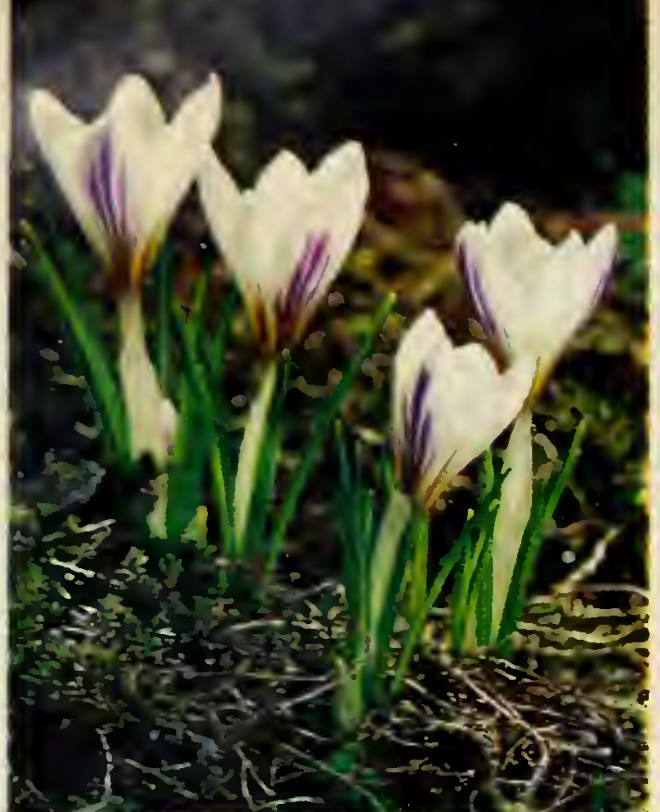

\section{A little bulb for garden charm}

Who says you can't plant crocus in a lawn? Here (picture 5) is a delightful scene of naturalized crocus edging the lawn. Generally, the crocus foliage matures before the lawn needs its first mowing, thereby assuring bloom year after year.

"Little" bulbs find a happy home in every garden. Here are some you can use to give color to the very early garden

CROCUS, no doubt, is the most popular of the minor bulbs. The charming striped varieties (pictures 4 and 7 ) always attract attention near walks where they can be seen close up.

LEUCOJUM (Snowflake) are easy to grow and thrive in any well-drained soil. They sometimes push through late Spring snows, as seen in picture 6

GALANTHUS (Snowdrop), as seen in picture 8 , can be left undisturbed for ten or more years.

ERANTHIS (Winter aconite) flowers are three to four inches tall and golden colored.

SCILLA (Squill) gives us blue flowers that bloom late

MUSCARI have little clusters of closeset bell flowers.

PUSCHKINIA grows four inches tall and bears a dozen or more silver-blue flowers.

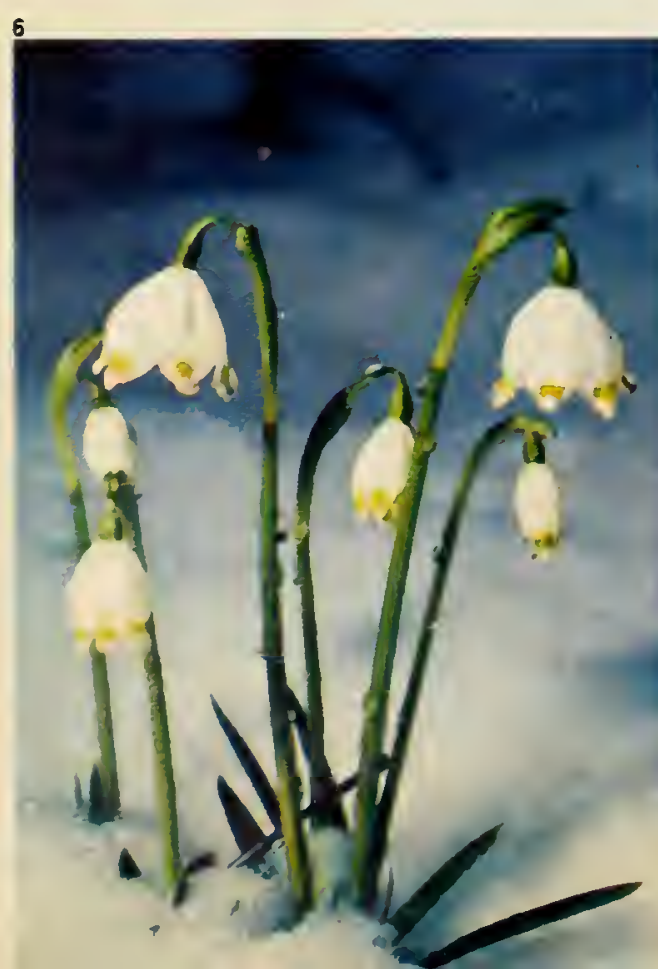

\section{Spring comes early with "little" bulbs}

Although the "little" bulbs are small in size, they are giants in performance. They are often the first flowers to announce the coming of Spring.

Spring truly comes early with the "little" bulbs

Coming from all parts of the world - the plains and mountains of Europe. Asia and South America their names spell out intrigue in the garden. Snowdrop, Winter aconite, Glory of the Snow, Anemone, and Snowflake are just a few.

Like all Spring-flowering bulbs, the "little" ones are planted in Fall. To add more pleasure, many set seeds and in a few years you will be treated to a solid carpet of color, returning year after year. They are also called "minor" bulbs.
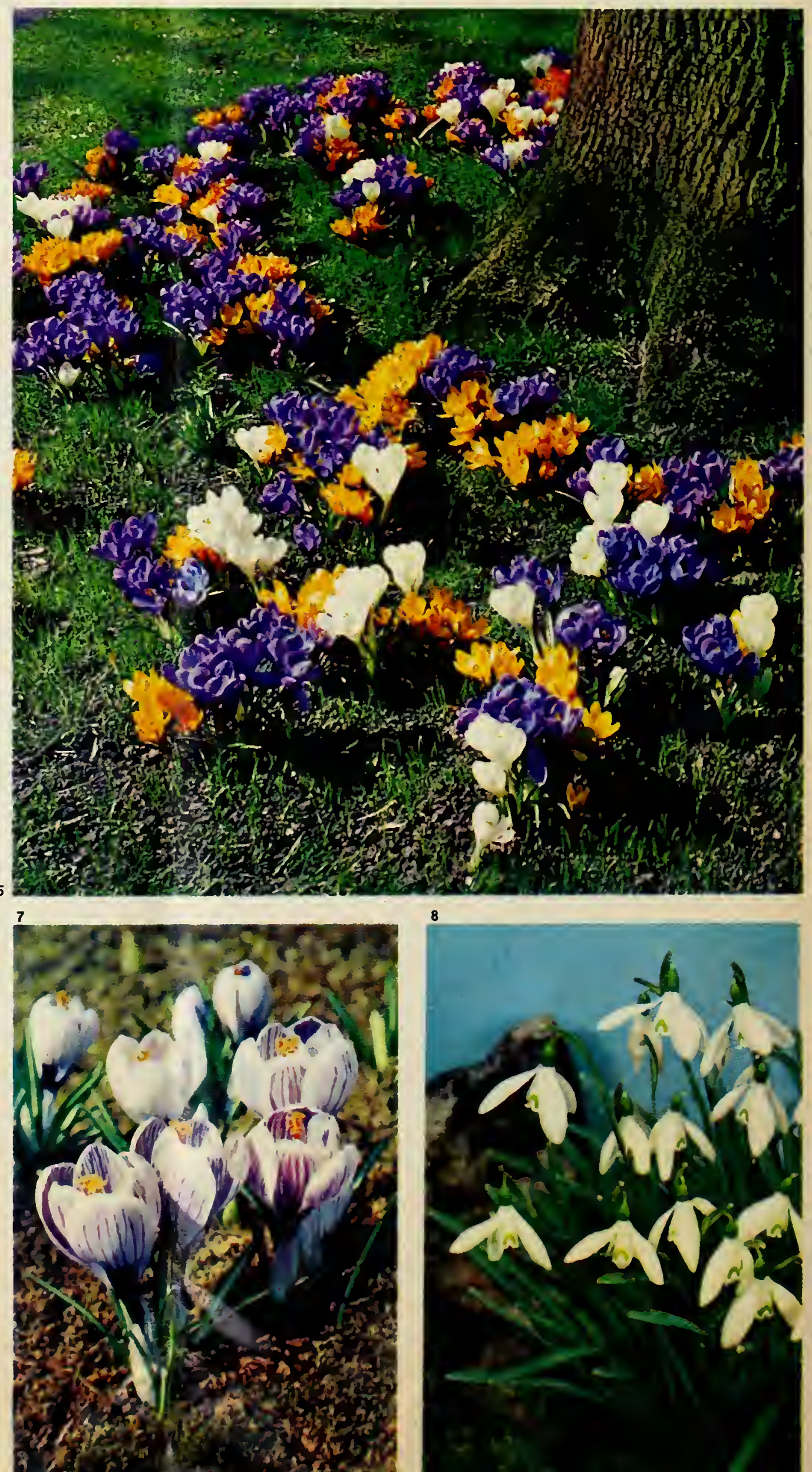


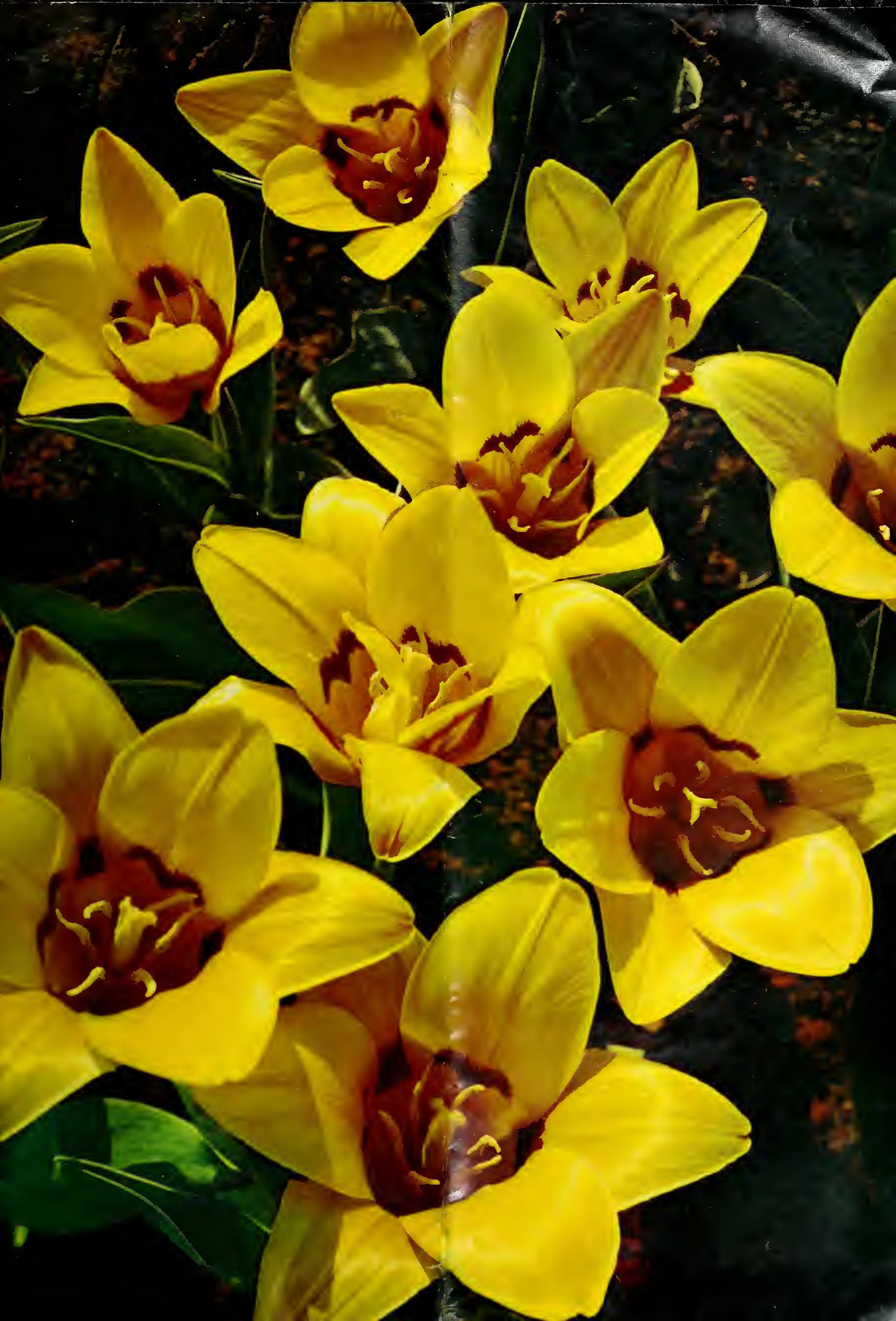




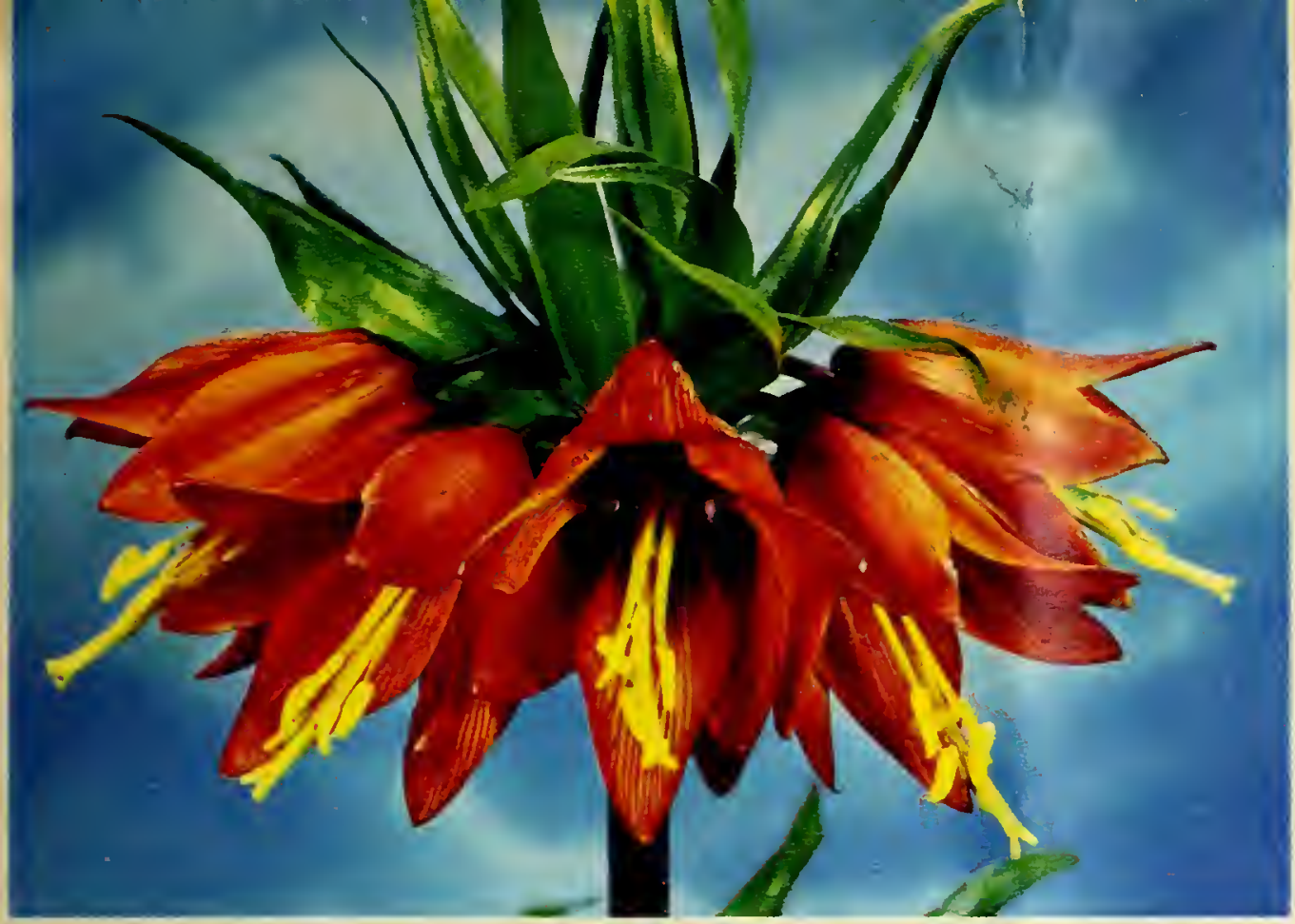

\section{Fritillaria}

The Crown Imperial, picture 14, certainly has a fitting name. The regal blooms are an accent in any garden. In addition to the typical orange Fritillaria imperialis, a yellow variety has also been developed.

A smaller "brother" of the Crown Imperial is Fritillaria meleagris as seen in picture 15. Smaller in size, it consists of variable checkered flowers.

\section{Daffodils for all Americans}

Although the yellow trumpet is the best known among the different classes of daffodits, it certainly is not the only one.

Pictured here are two classes that could adorn any garden. Picture 16 is the short-cupped daffodil. Contrast this with the large-cupped type in picture 17.

Daffodils are the Spring bulbs for every American and Canadian gardener. Among the many classes or types there is at least one that can be grown in every climate from the warm shores of the South to the cold areas of the North.

With nodding heads and graceful stems, these ballerinas of the garden give pleasure and color year after year once settled in their home in the soil.

Where many classes can be grown, a selection will give you a long blooming season.
16

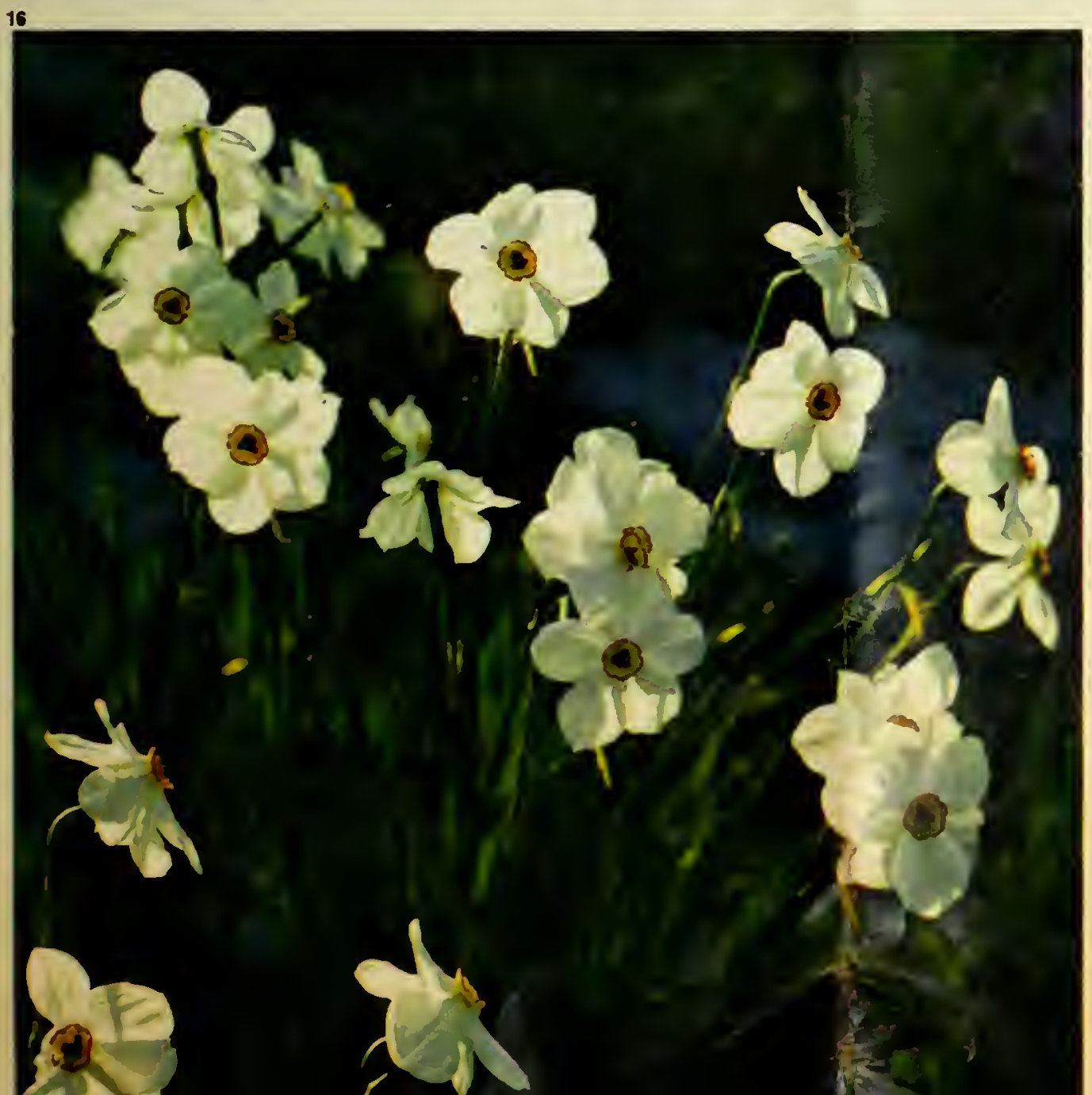

15

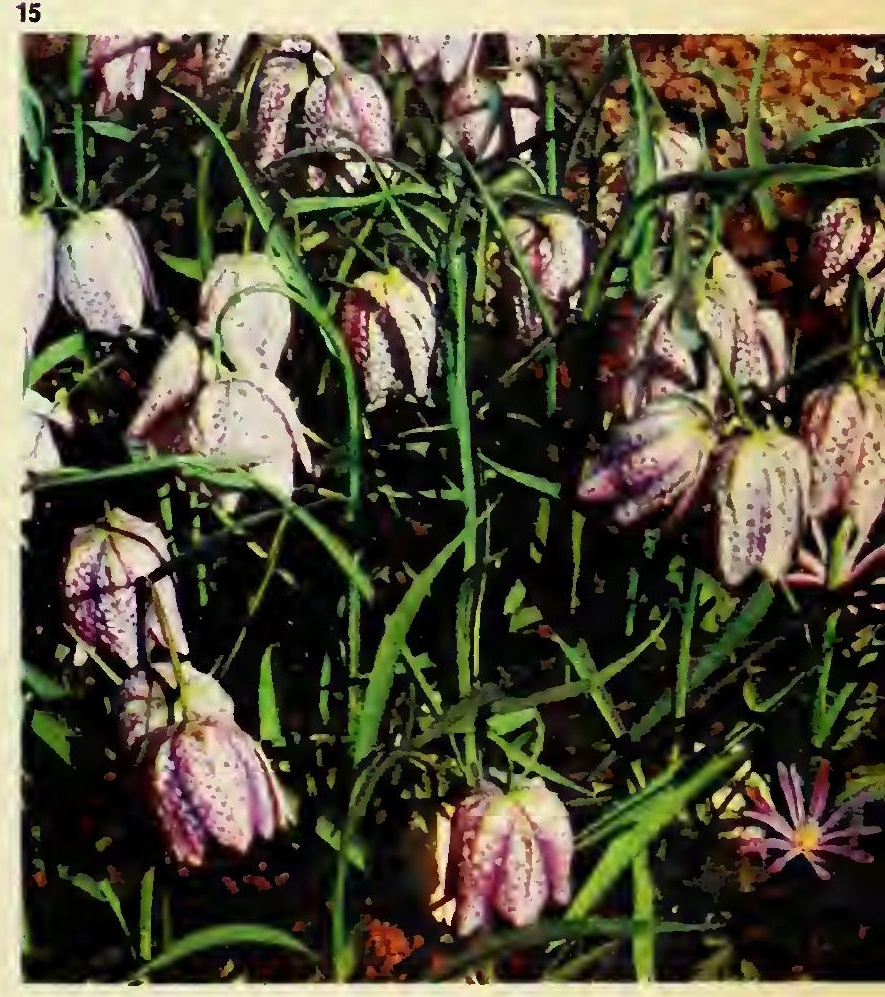

17

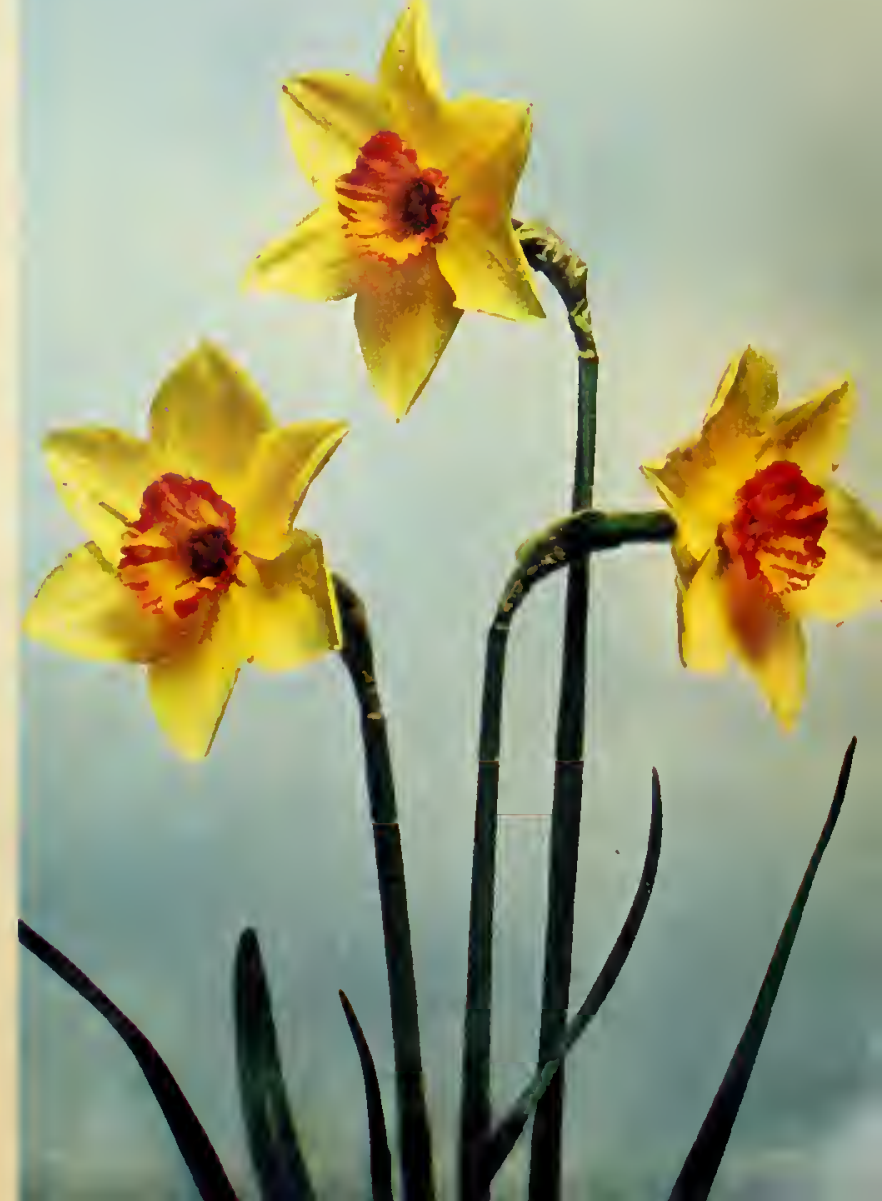




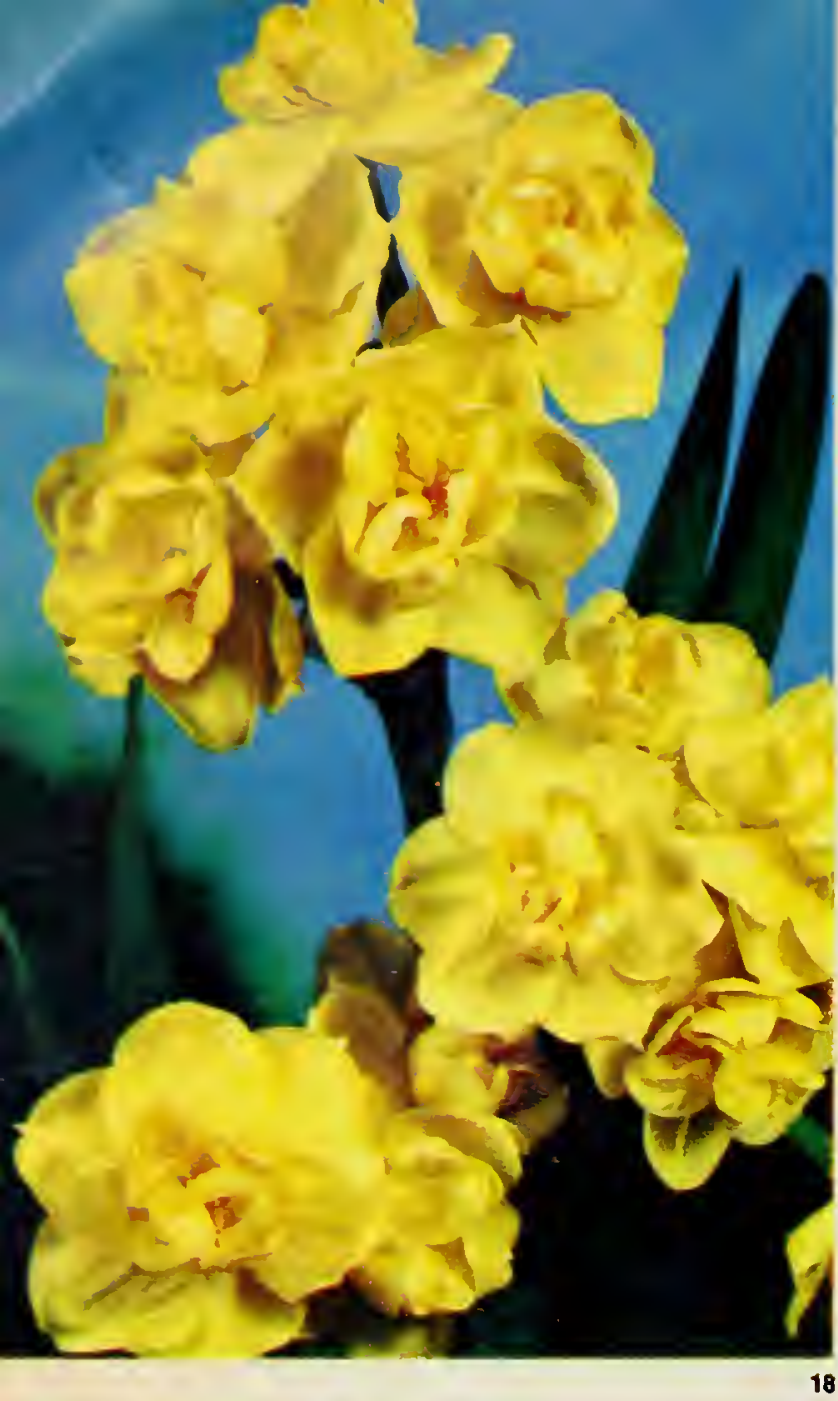

18

\section{Unusual forms in bulbs}

A daffodil that looks like a rose ...tulips that look like peonies or lilies... these are things you can have in your bulb garden next Spring.

Doubleness in bulbs certainly has its place. A mass planting of Double Early or Double Late (peony-flower) tulips is a sight to behold. The full rounded blossoms are unlike anything else in the large tulip family.

Double daffodils can sometimes give the illusion of tiny roses rather than what we think a daffodil should be.

The unusual among tulips can be extremely striking. Take, for instance, the Parrot tulip with its fringed petals and feather streaking of green.

Double tulips are true garden sophisticates. To have them show up to their best, plant them in groups of a single color with a plain background such as a formal clipped hedge or brick wall.

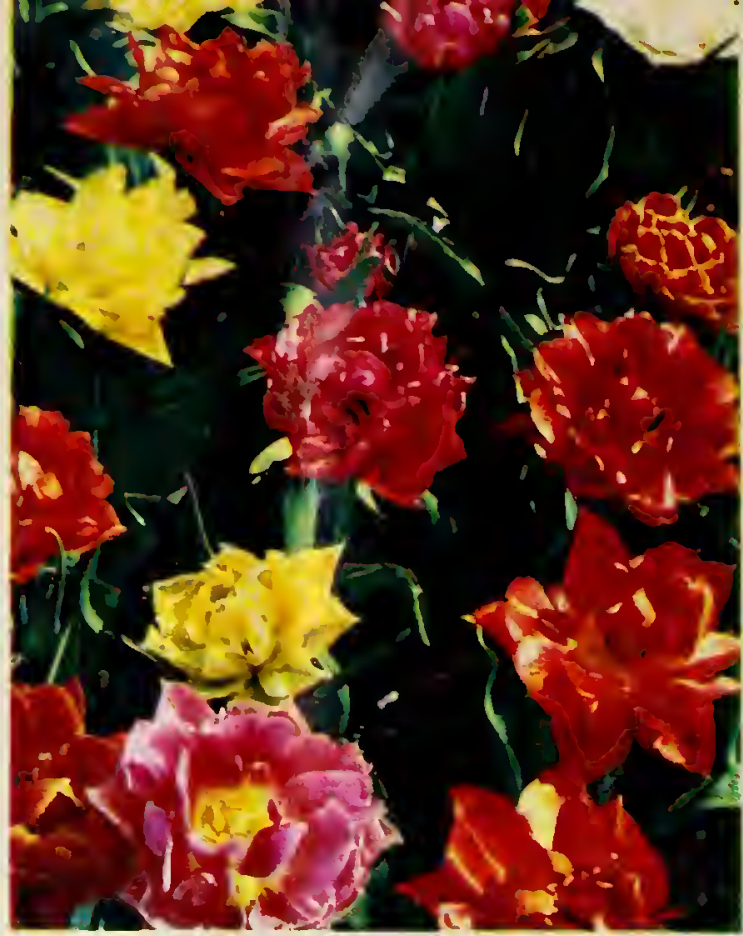

19

Unusual? Different? Yes, but, they are all Spring-flowering bulbs. There are many "different" or "unusual" shapes to be found in the magnificent world of Spring bulbs. Look closely at the double daffodils in picture 18. The "peonies" in picture 19 are really double tulips, a favorite of many gardeners. The Parrot tulip class is exemplified in picture 20 with its fringed petals and streaks of green.

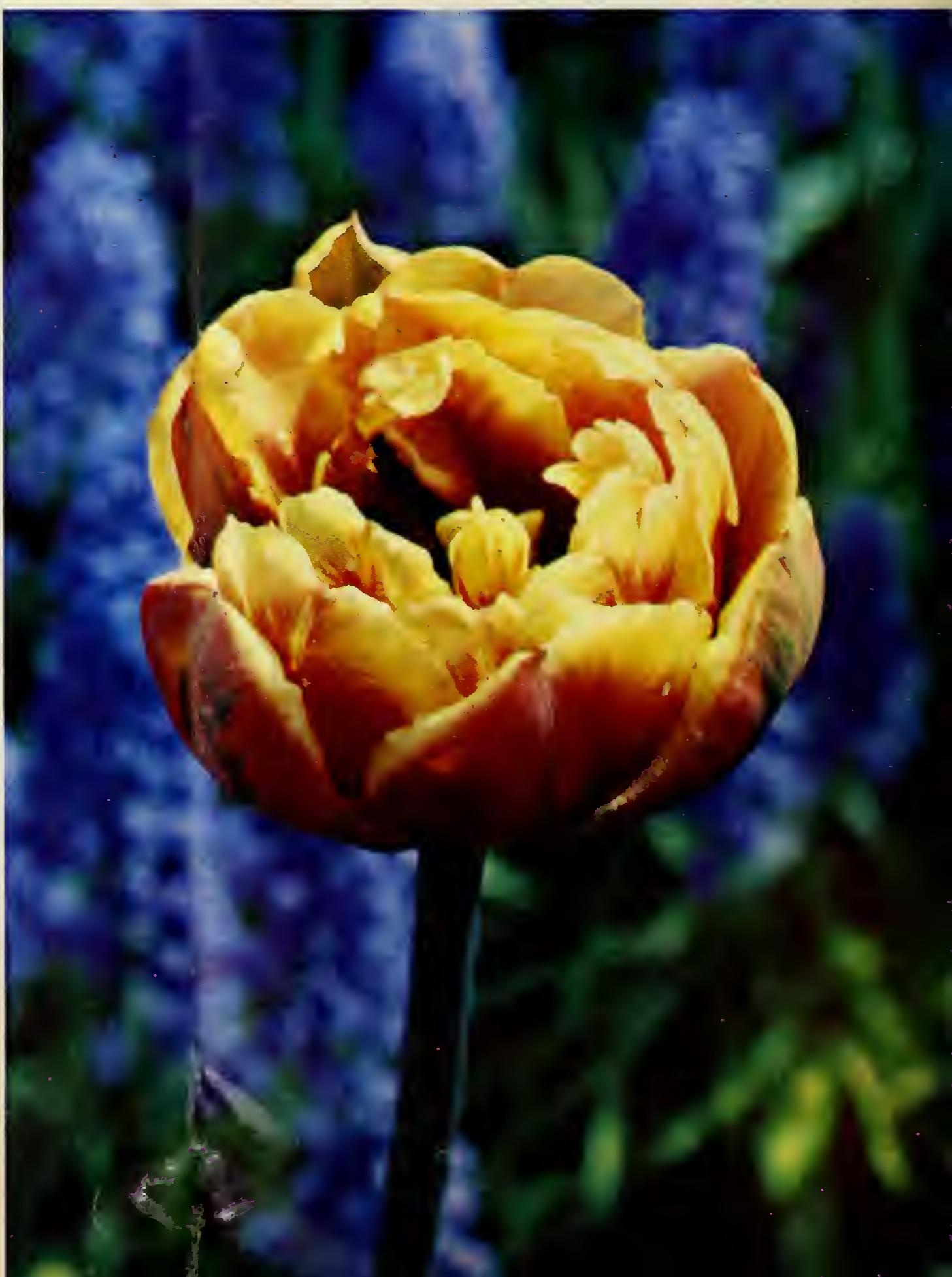




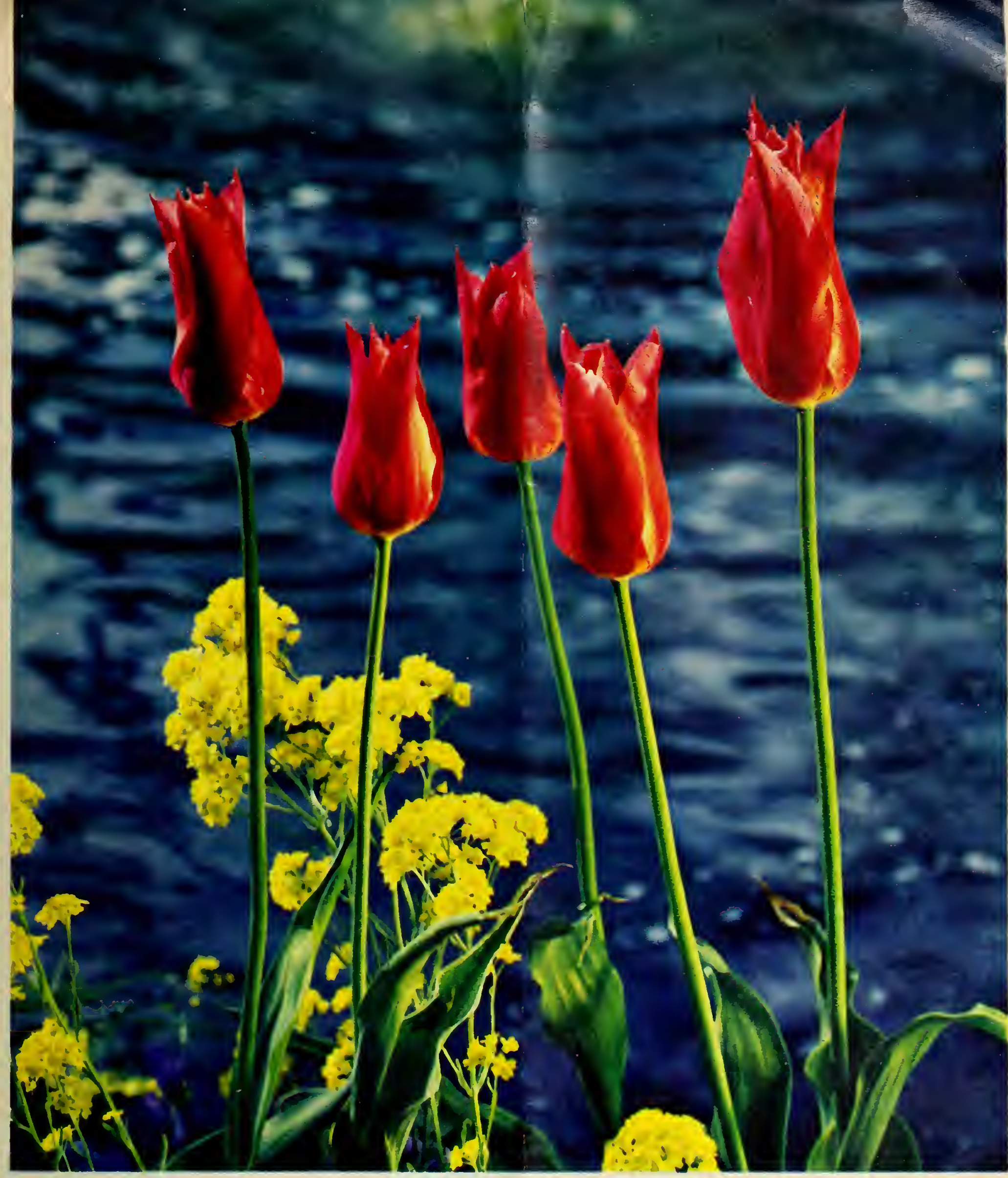

22

23

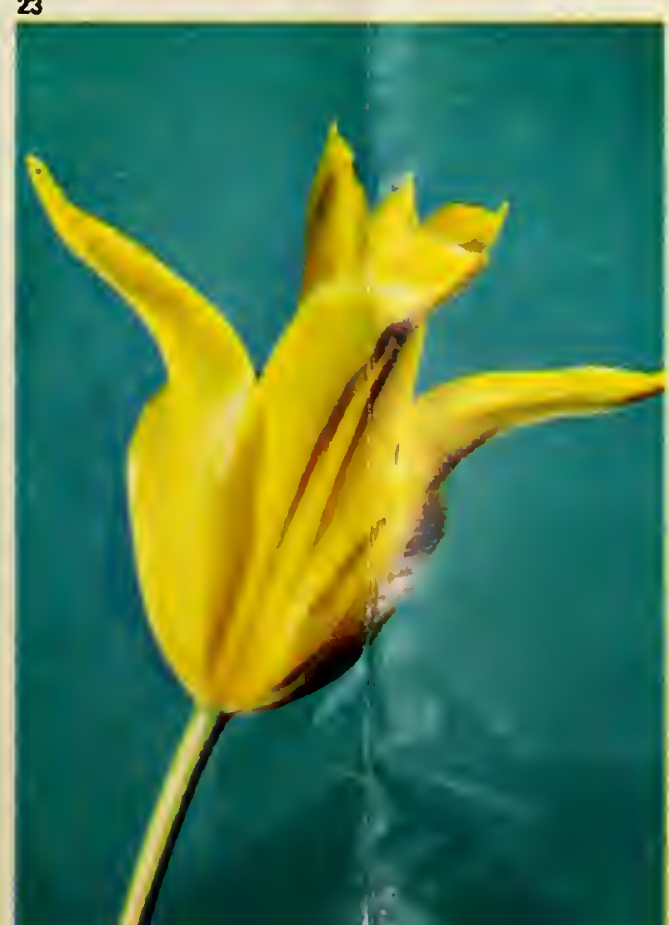

24

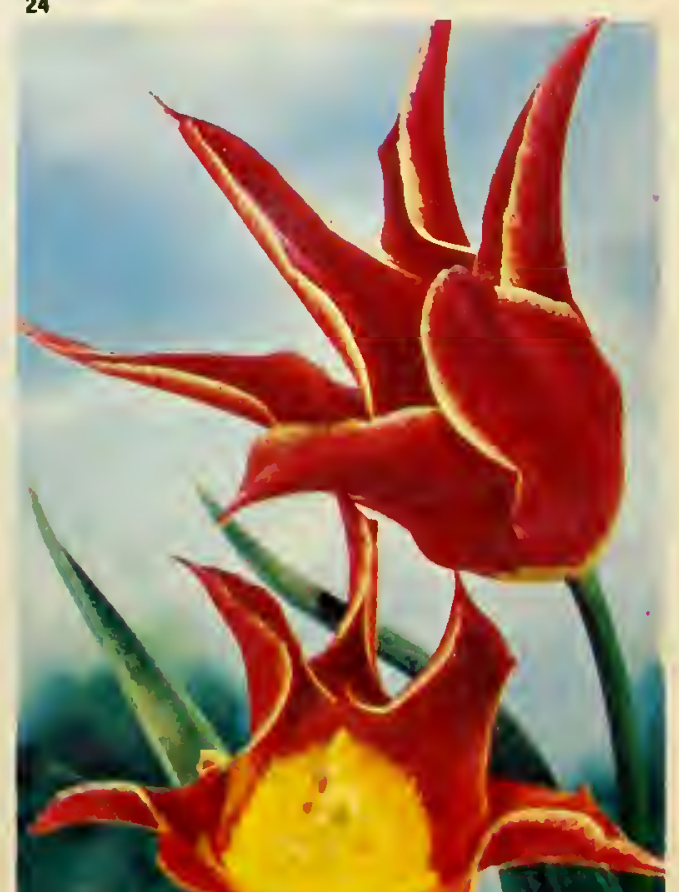

Grace and charm distinguish the class of Lily-flowered tulips. The tall, slender stems are remarkably strong. As they wave in the breeze, the slender buds and pointed petals are the epitome of delicacy. Within the Lily-flowered class of tulips there are many varieties and a multitude of colors (pictures 22, 23 and 24). 


\section{Tips on tulips}

The tulip can be one of the most rewarding of all garden flowers. It comes in a rainbow of colors, shapes and sizes. Among the many classes there are the early-blooming species or botanical tulips, some of which are among the first bulbs to bloom in Spring.

From these little and early tulips there is a full range of single and double types, up to the majestic Darwin Hybrid class, an example of which is seen in picture 26.

Tulips are not "demanding" plants. The Fall-planted bulbs should be set in well drained soil. Except for the species tulips, plant them six inches deep and apart. Smaller species tulips are planted four inches deep and apart. Water the bed after planting and wait for the Spring color.

Plant tulips in clusters or groups of a dozen or so. For a real splash of color, try mass planting fifty or more. Such a bed will be the talking point of the neighborhood next Spring.

After blooming in Spring, leave the foliage on the bulb until it has turned brown and "matured." Nourishment for the newly-forming bulb - and next year's flower - comes from the green foliage. However, nip the flower off, leaving the stem, as soon as color starts to fade.
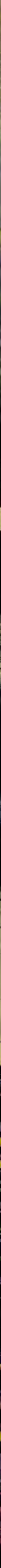

27
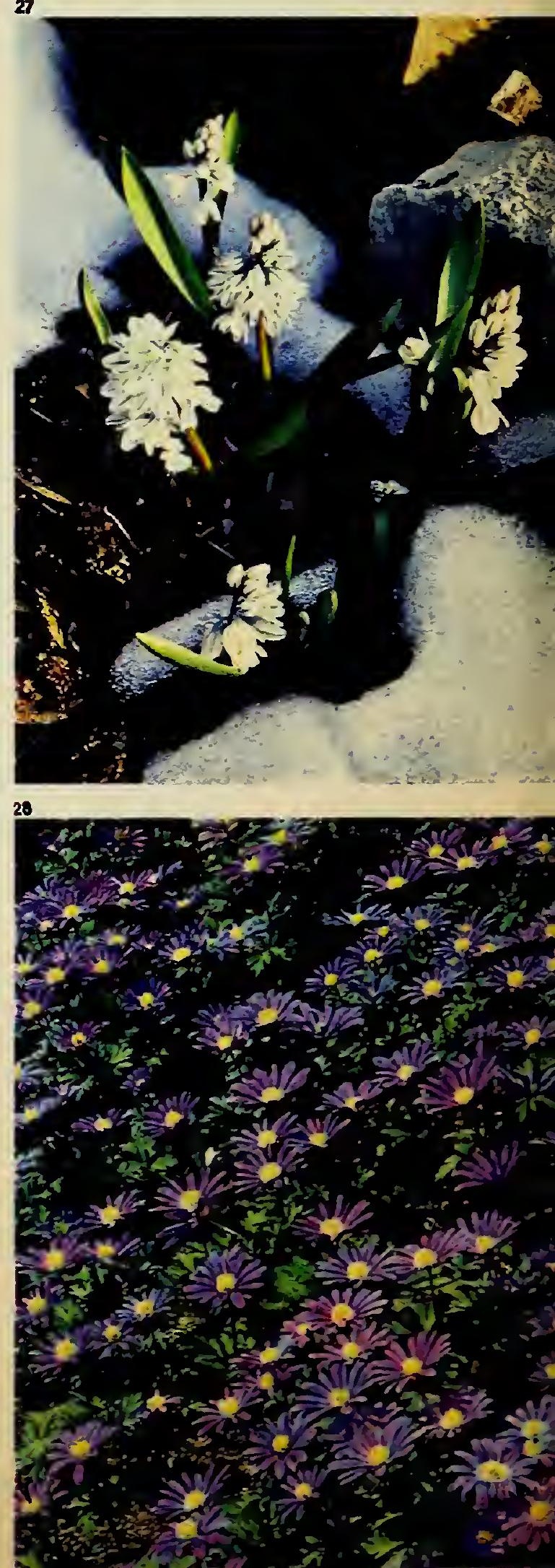
Glory-of-the-Snow with sky-blue flowers (picture 25) is a welcome sight in the early bulb garden. The bulbs are best planted by the hundreds for a drift of color.

The early-blooming Squill (picture 27) will often poke its head through March snows. Anemones, picture 28 , in a sunny location can be most enchanting year after year.

\section{Beautiful}

\section{hyacinths}

\section{for a Beautiful} America

Whether planted in free form or a formal design, the hyacinth presents a rhythmic balance to all gardens. Long treasured for their perfect blossoms and heady, Springlike fragrance, hyacinths are ideal for adding unexpected accents of color and sharply defined form to modern, contemporary gardens for a more Beautiful America.

The growing habits of hyacinths are irreproachable. And their colors are the epitome among pastels in the garden.

One interesting way to plant hyacinths is in square patches at regular intervals along drives or lawn edges. The colored squares of rectangles of varicolored hyacinths look for all the world like little cakes of colors in a child's paint box.

In addition to color, hyacinths add the dimension of a most pleasing fragrance. For this reason, they are most enjoyable on patios and terraces.
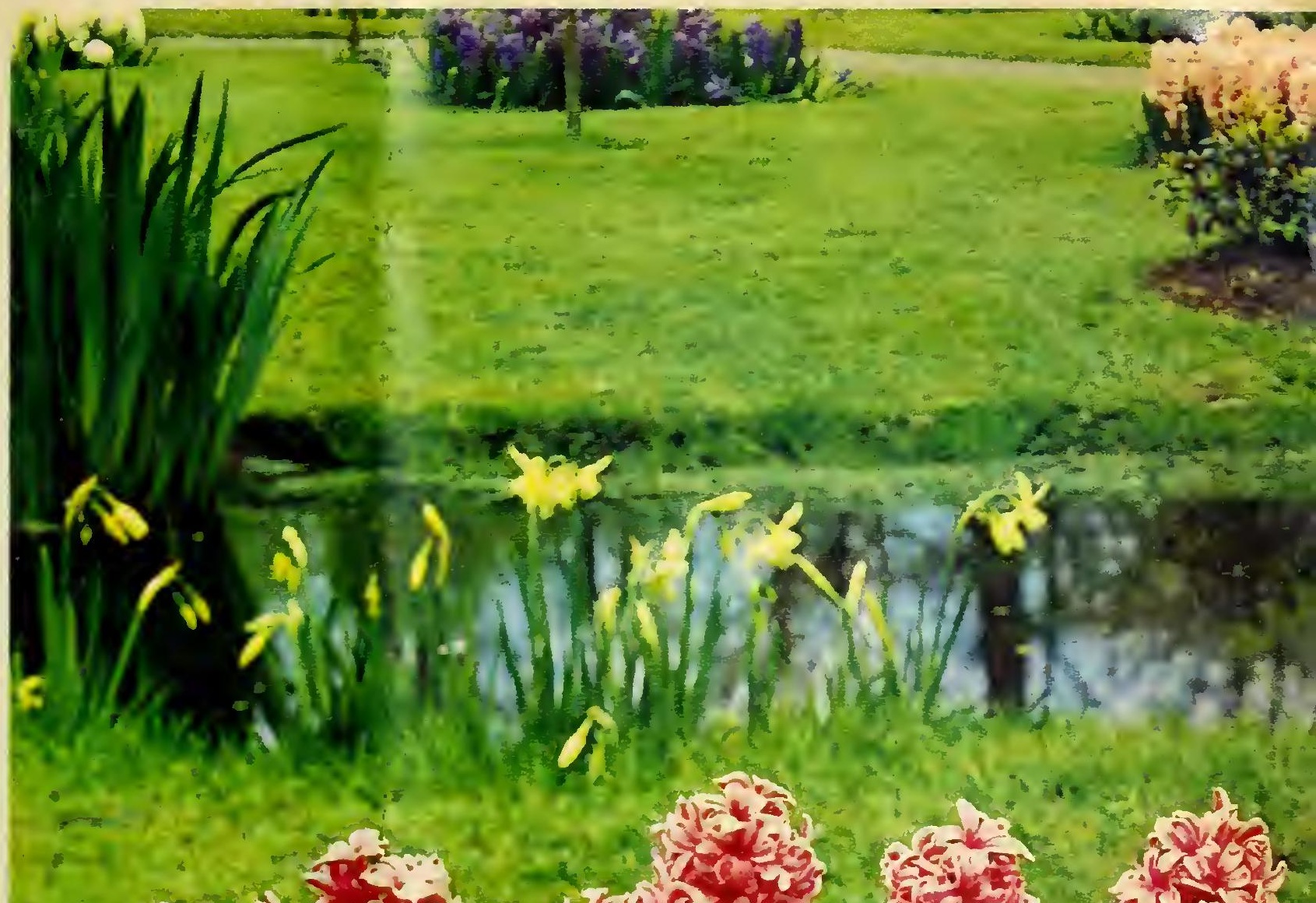

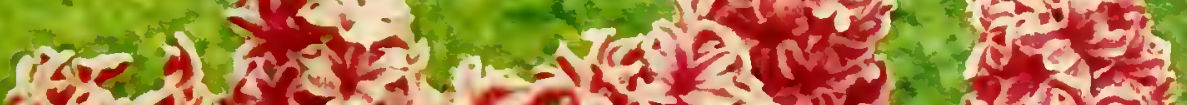

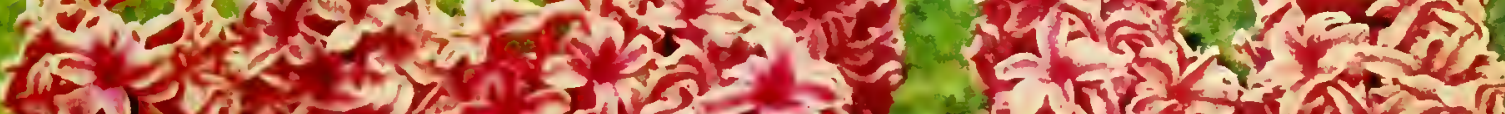

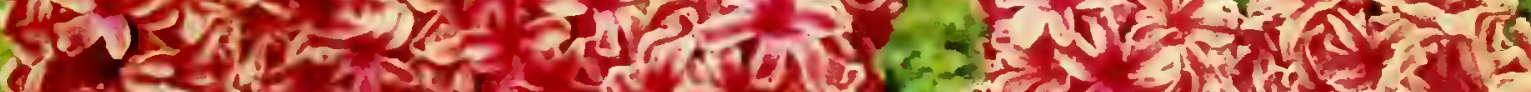

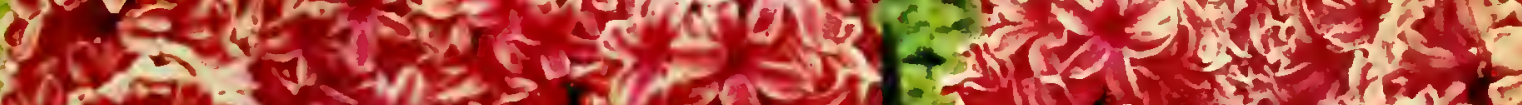

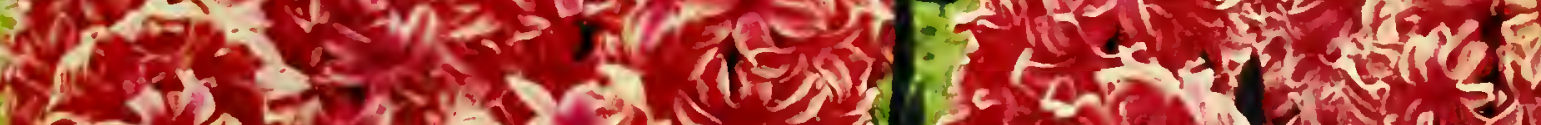
if

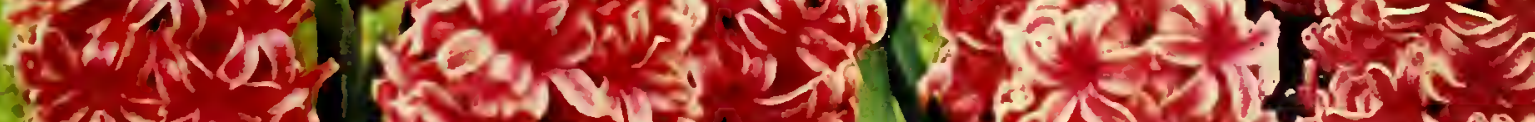

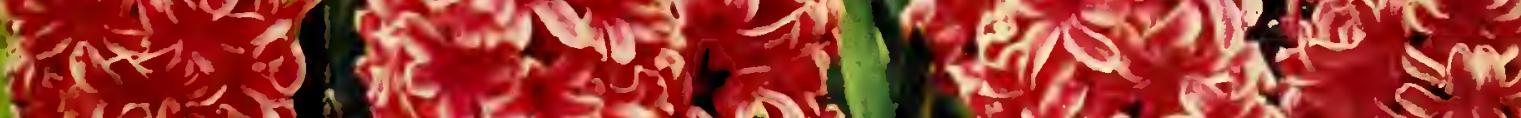

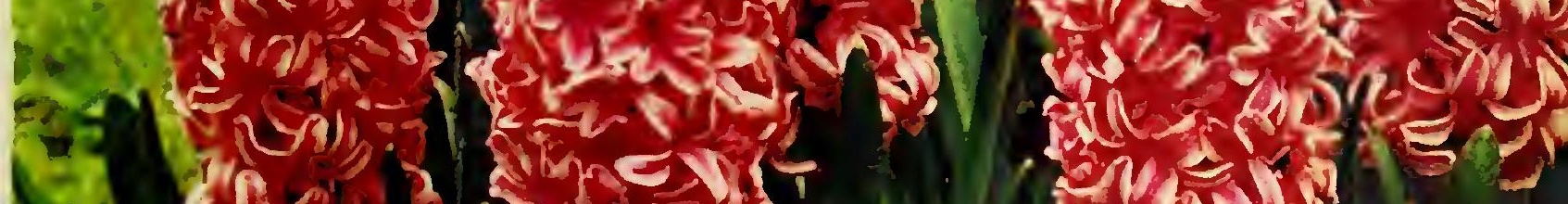

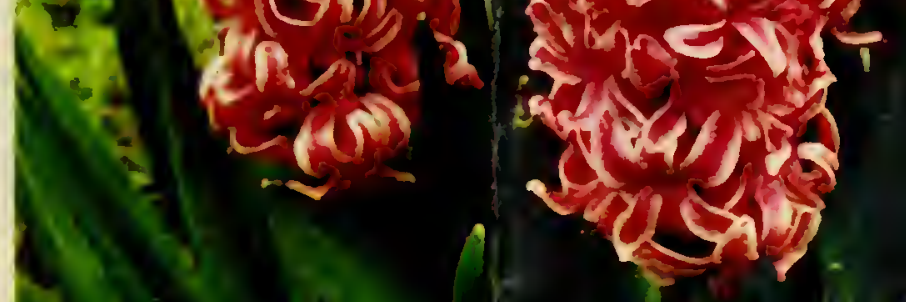
$12(2,1)$

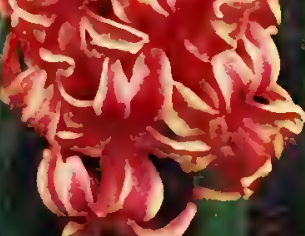
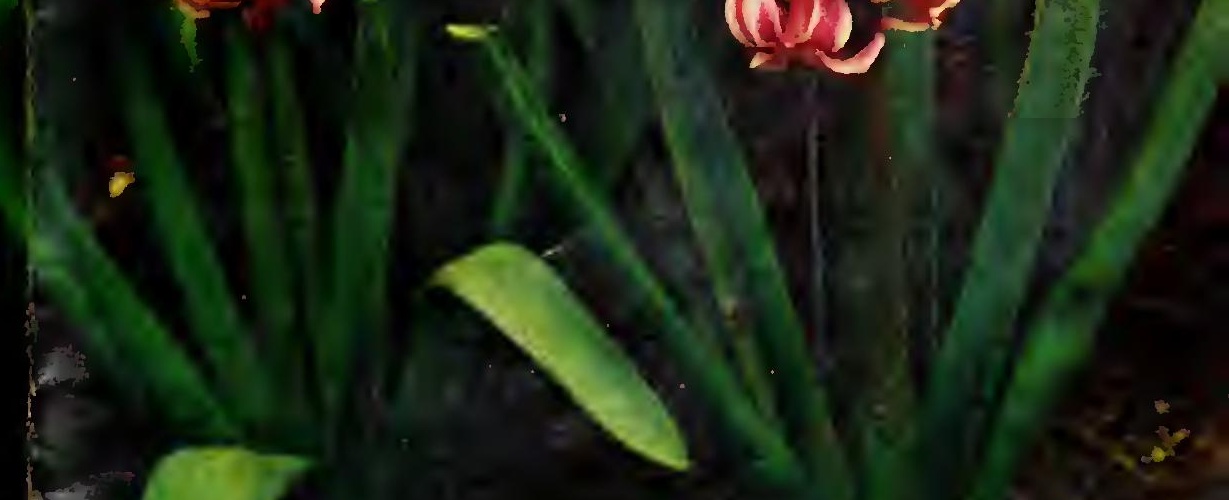

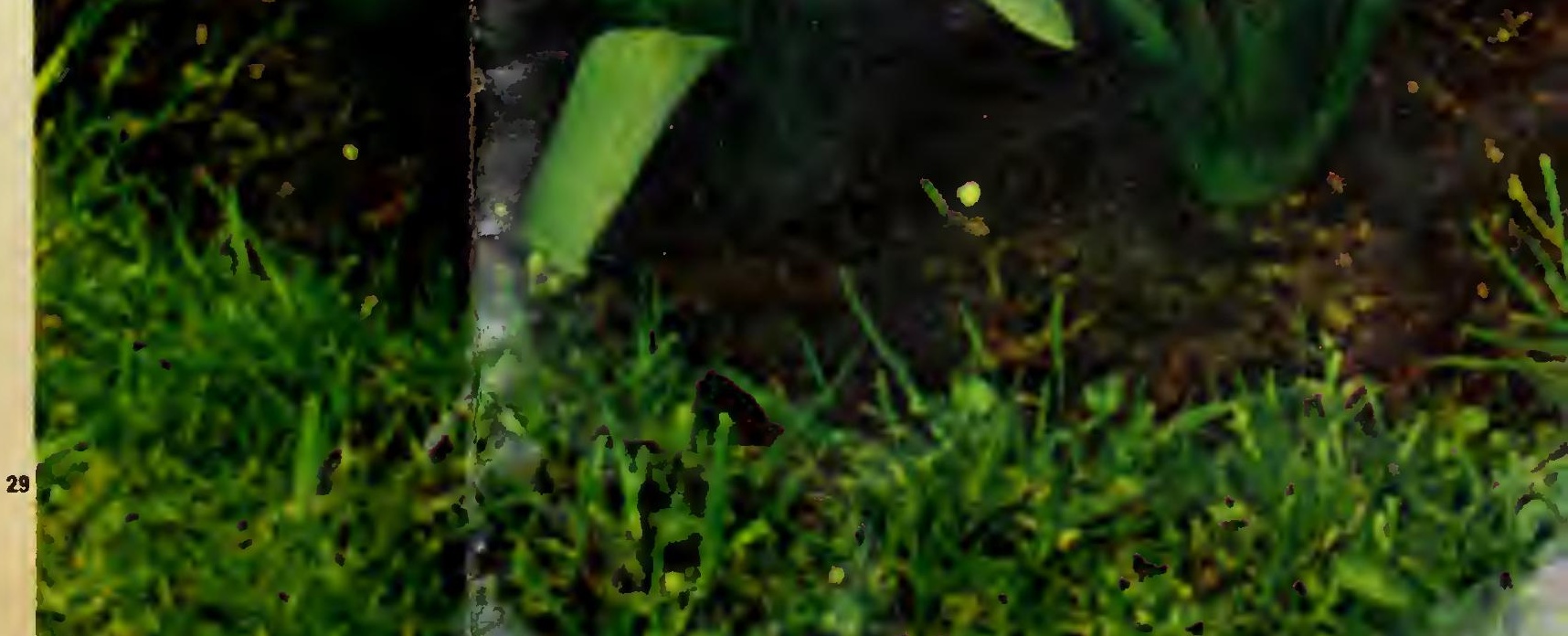




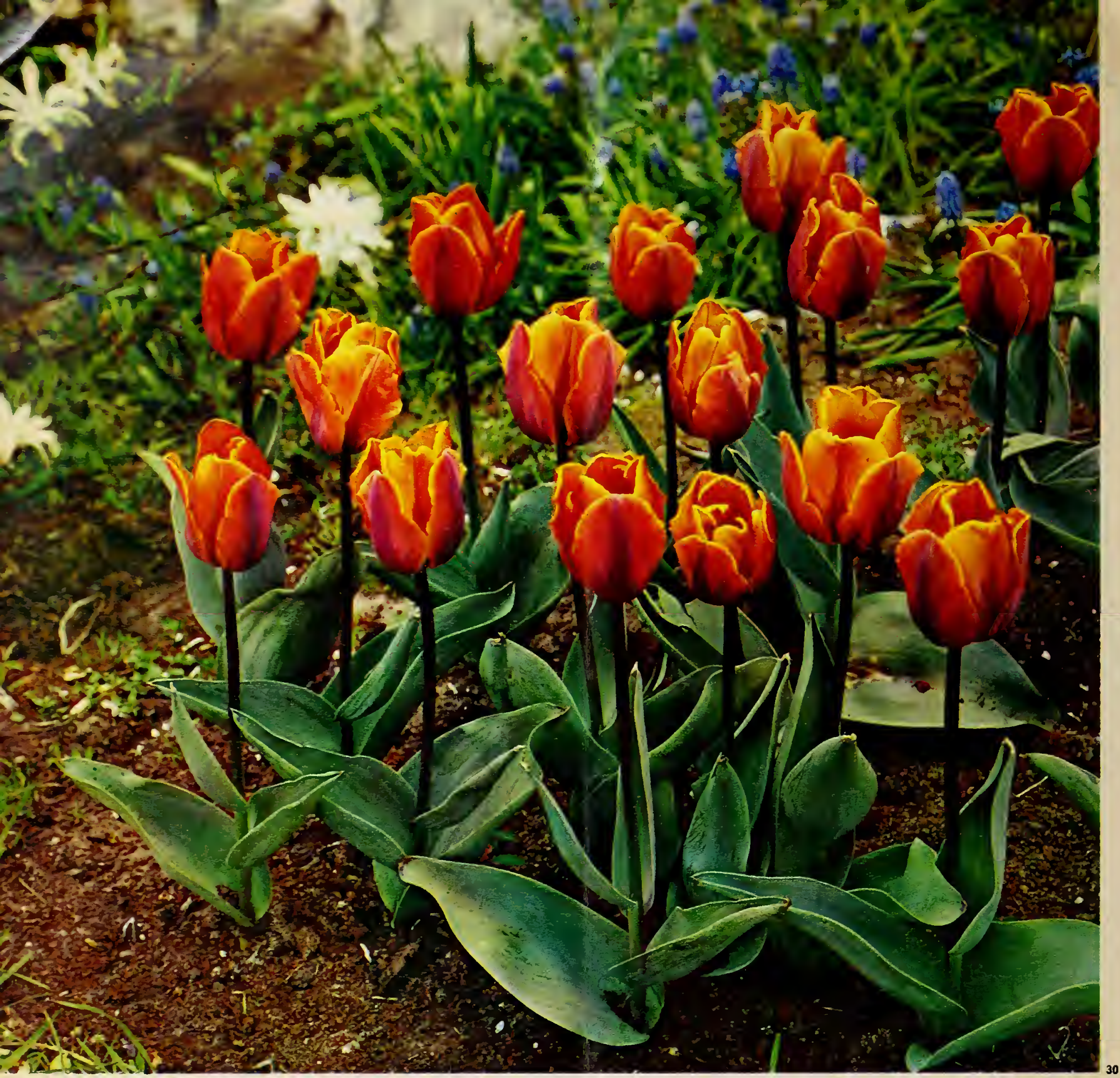

\section{Tulip: Queen of flowers}

Landscaping with tulips is a delight offered by few other flowers. There is a tulip to suit your particular taste, as well as landscape situation.

There are short tulips that are perfect for interplanting among shrubs or at the base of a tree. Tall tulips of vivid colors, such as the "Triumphs" in picture 30 , will stand alone as a color accent for a more beautiful garden in a more Beautiful America.

Adorning a dooryard planting, as in pictures 32 and 33 , tulips add a festive note of cheery welcome to the house.

Tulips flower at the time Nature is awakening from Winter slumber into a vibrant new life. They give the first full panorama of Spring color, and are enjoyed by all.

Sharing this joy is easily accomplished by joining with neighbors and providing a selection of tulips for the local school or library. Just as the stately tulip flowers add to the decor of the home garden, they will be a delightful addition to a public building planting.

The adornment of the grounds of public buildings is an integral part in the overall program to Beautify America. In gardens with other plants, as a group by themselves or with the shrubs of a public building planting, tulips will do the job of creating more beautiful gardens - the main link in making ours the most beautiful land in the world. 


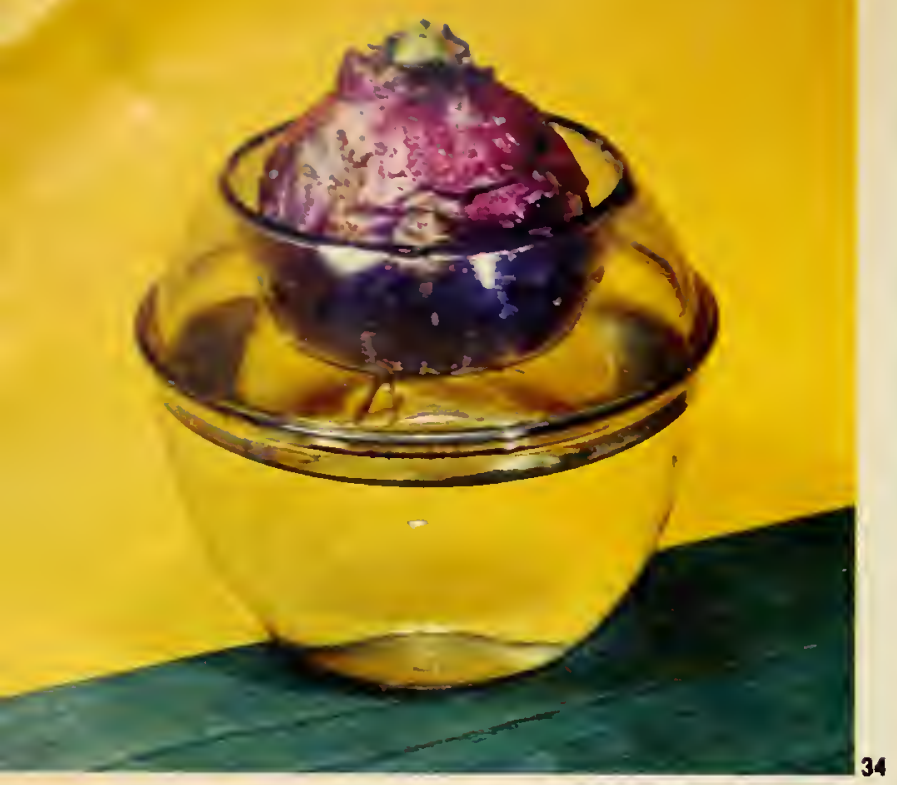

\section{A Beautiful America year after year}

The Beautify America Program will continue for many years. Many of the vast projects initiated by government agencies, both on federal and local level, are just now getting under way.

There can be no doubt that the part of the Beautify America Program in the hands of the homeowner and gardener will continue for many years to come.

The ultimate goal should be to institute plantings that will add beauty year after year. Along with the proper selection of trees and shrubs, you can count on your bulb flowers to give continuous color accents.

Many of the tall, stately tulips will bloom for years if given the proper care.

For permanence in a planting, there are few showier flowers than the daffodil to give many years of dramatic color.

Minor bulbs are noted for their permanence. Left undisturbed, many will last for ten years. Others will set their own seed, and from a handful of bulbs, a complete drift of color will result.

When planning your bulb planting, do sections at a time. Take one portion of your garden and complete the planting. The following year, take another garden section so the second Spring you will reap the enjoyment of two "complete" garden scenes.

Bulb flowers always are more satisfying when they appear in groups or clumps. Tulips, daffodils and hyacinths look best in clumps of a dozen or so. Small bulbs, like the crocus, should be drifted in plantings of 25 or 50 .

For naturalizing the edge of the garden or a meadow, nothing surpasses bulb flowers. Daffodils are very well suited to a naturalized planting. When left undisturbed and given a feeding once a year, the natural effect of daffodils is more enchanting as years pass by.

\section{- Bulb flowers to beautify}

\section{the indoors, too}

The beauty in America should not stop as you enter the door from the outside. From mid Winter through early Spring, bulb flowers can bring the color and fragrance of the outdoors inside the home, despite inclement weather without.

A multitude of fresh cut and potted bulb flowers are available from florists in late Winter and early Spring; but, it is also possible for you to force your own potted flowers.

Watching a bulb flower develop indoors is an education for the entire family. Children will gaze with fascination at the entwining roots of a hyacinth forced in a special glass; as seen in pictures 34,35 and 36 .

Pots and flats of tulips, daffodils, hyacinths or crocus can also be forced indoors with a minimum of 36 care, as seen in picture 37 . Your dealer has a special booklet on forcing bulb flowers indoors - ask him for a copy.

Throughout the Winter months, many bulb flowers are available from local florists. When purchased in the bud stage, they will give days of enjoyment in artistic arrangements.

For an extended life indoors, bulb flower stems should be cut at an angle so they can absorb water more easily.

Daffodils and iris can be artistically arranged in a shallow dish of water about an inch or so deep. For bouquets and tulips, use a deep container with as much water as possible.

Bulb flowers are truly double-duty gems. Enjoy their flowers outdoors and indoors as well. 


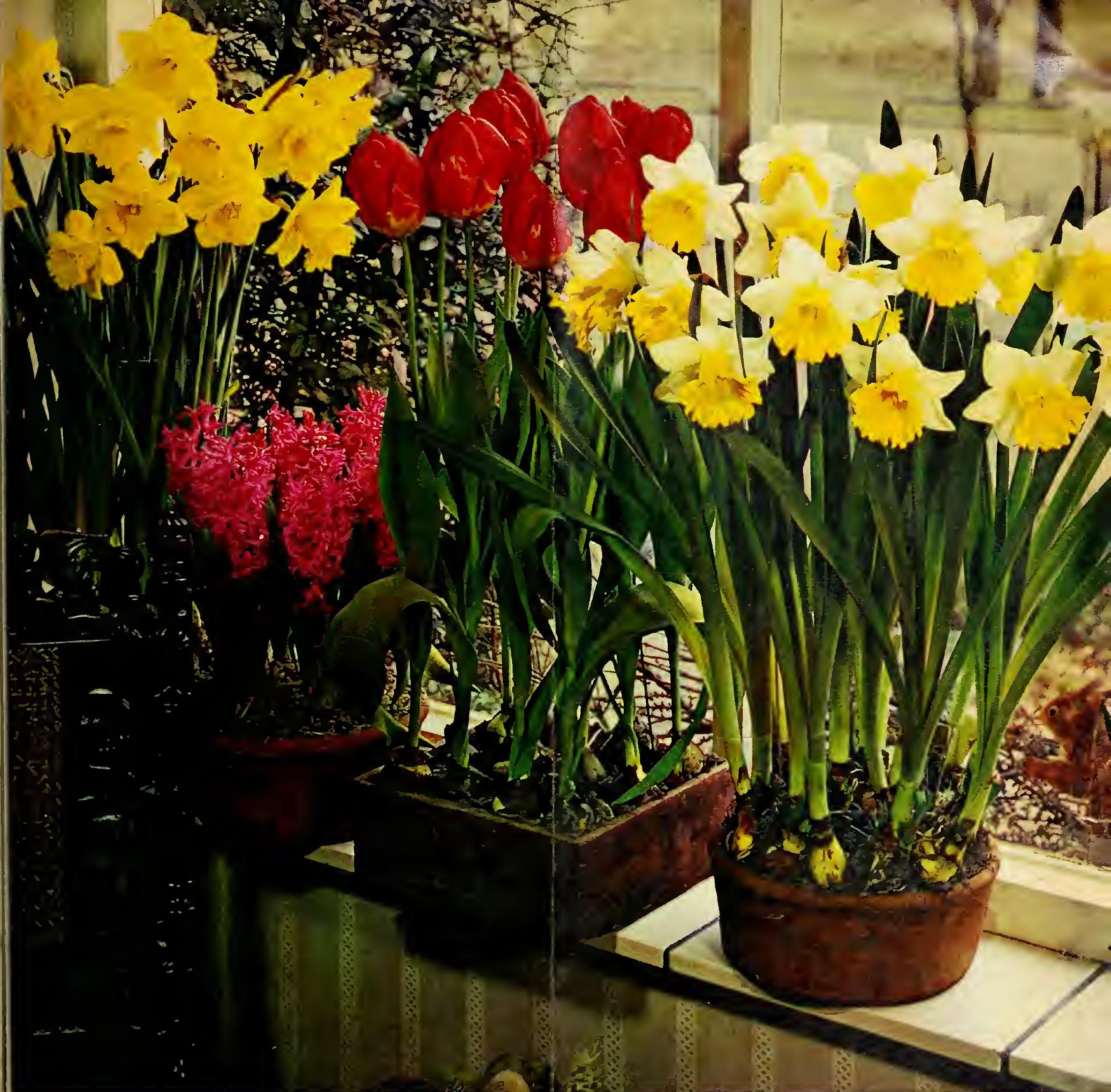

\section{A salute to Canada}

The vast program that has been undertaken by the United States government and interested citizens to Beautify America is not unknown to its neighbors to the North. Canada is also a part of the North American continent, hence Beautify America could also include this great country.

No closer relationship between two countries is enjoyed anywhere in the world than that of the United States and Canada. Just as there is a free access of visitors and trade. so too is the exchange of ideas and horticultural knowledge.

Gardeners in the United States can garner much from the plantings and landscapes of Canada. Springflowering bulbs abound in Canada, and the city of Ottawa, the capital, claims the second largest planting of bulbs in the world. Its annual tulip festival has become a major attraction for visitors from the United
States as well as Canada.

The enjoyment of Spring-flowering bulbs is universal in both countries. Although planting dates may be the same, flowering may be later in Canada. But the sequence is the same and by proper selection of classes of tulips, daffodils and other bulbs, it is possible to have nearly two months of color in your garden whether in the United States or Canada. 
